\title{
Re-examining Nuremberg as a New Deal Institution: Politics, Culture and the Limits of Law in Generating Human Rights Norms
}

\author{
By \\ Elizabeth Borgwardt*
}

Major Airey Neave, famous at age twenty-nine for his multiple escapes from Nazi prisons, noticed the unusually brilliant shine on Colonel Burton Andrus' helmet, as the two officers stood waiting outside the prison wing of the Palace of Justice at Nuremberg on the afternoon of October 19, 1945. Neave was a German-speaking London barrister whose wartime heroics with the clandestine British intelligence service, MI-9, had involved disguising himself variously as a Dutch electrical worker, a German corporal, and a German artillery lieutenant. ${ }^{1}$ The afternoon before, Francis Biddle, former U.S. Attorney General and the American judge at Nuremberg, had cavalierly informed Neave that the young major was to serve copies of the Nuremberg Charter, along with a detailed criminal indictment, on the Nazi leaders incarcerated in the Palace of Justice. $^{2}$

\footnotetext{
* Assistant Professor of History, University of Utah. J.D. (Harvard); Ph.D. (Stanford); M.Phil, International Relations (Cambridge).

1. Major Neave had escaped from the supposedly escape-proof Nazi prison in Colditz Castle, Saxony, a feat which so impressed the senior members of London's Middle Temple that they waived his final Bar examinations. He learned German as an exchange student in Berlin in 1933, where he unwittingly participated in a Nazi youth march. His memoir, although not published until the late 1970s, was based on his contemporaneous notes and on a memo he filed with the Nuremberg Tribunal in 1945. See Airey Neave, Memorandum for the General Secretary of the International Military Tribunal (Oct. 24, 1945), PRO/LCO 22982 x/LO6978; AIREY NEAVE, NUREMBERG: A PERSONAL RECORD OF THE TRIAL OF THE MAJOR NAZI WAR CRIMINALS IN 1945-46, at 19-22 (1978) [hereinafter PERSONAL RECORD].

2. Throughout this study, "Nuremberg" refers to the trial of twenty-two top-ranking Nazi leaders held in the Palace of Justice at Nuremberg in 1945-46. Transcripts published as 1-42 TRIAL OF THE MAJOR WAR CRIMINALS BEFORE THE INTERNATIONAL MILITARY TRIBUNAL, NUREMBERG, 14 NOVEMBER 1945 - 10 OCTOBER 1946 (1947-49) [hereinafter IMT NUREMBERG]. Twelve other U.S.-sponsored war crimes trials were held at Nuremberg between 1946 and 1948 of roughly two hundred so-called second-tier Nazis, such as judges, industrialists, police, doctors, and scientists, resulting in eighteen executions and thirty-eight acquittals, with the remainder receiving lesser sentences. The transcripts of these trials are published as 1-15 TRIALS OF WAR CRIMINALS BEFORE THE NUREMBERg TRIBUNALS UNDER CONTROL COUNCIL LAW NO. 10, OCTOBER 1946 - APRIL 1949 (1946-49). See also TELFORD TAYLOR, FINAL REPORT TO THE SECRETARY OF THE ARMY ON
} 
Major Neave's initial assignment in post-surrender Germany was to gather evidence on the Krupp family's wartime use of slave laborers in its armaments factories. When this project stalled due to questions about the declining health of the Krupp patriarch, Neave was reassigned as an aide to the justices at Nuremberg. "You look remarkably young," the nasal-voiced Biddle observed in passing. Upon receiving these instructions, the young British war hero recalled, "I had several moments of unreasoning panic. I felt as if I were suddenly invited to sing at Covent Garden. It was like a nightmare in which I was endeavouring to lecture on higher mathematics."3

Disgusted by the abundant evidence he had already reviewed in connection with his Krupp assignment, not to mention his own wartime imprisonment and interrogation at the hands of the Gestapo, Neave dreaded his imminent personal encounter with these "high priests of Nazism."4

I.

"THE VICTOR WILL ALWAYS BE THE JUDGE AND THE VANQUISHED THE ACCUSED"

The Nuremberg Charter that Neave was to deliver spelled out the charges against twenty-four individual defendants and seven "defendant organizations" under three counts: crimes against peace, war crimes, and crimes against humanity. ${ }^{5}$ Each of these three counts had a specialized content. Crimes against peace encompassed both the "planning, preparation, initiation, or waging of a war of aggression" and "participation in a common plan or conspiracy" to wage such a war, in violation of treaties and international agreements such as the 1928 Kellogg-Briand Pact. In other words, the Nazi leaders were being charged with

NuREMberg War Crimes TRials Under CONTROl COUNCIL LAW No. 10, at 159-217 (1949). With minor variations, these "secondary" Nuremberg trials were governed by the same charter as the main trial. In the Far Eastern theater, the Tokyo Trial of twenty-eight Japanese leaders was also governed by a virtually identical charter to the one at Nuremberg.

3. PERSONAL RECORD, supra note 1 , at 53.

4. Id. at 39. Major Neave's perception of the defendants was clearly influenced by his preliminary Krupp investigation, which indicated that the Krupp family and its business directors had enthusiastically abused over seventy thousand foreign-born workers, many of them HungarianJewish children. Neave was especially shocked to learn that the exploitation of this forced labor had been voluntary-_"even Hitler was surprised that a company like Krupp would insist on doing so"and that the Krupp family and its senior employees "expressed no regret for anything" at any time. See id. at 39-41. Gustav Krupp von Bohlen und Halbach had been named as a defendant at the main Nuremberg trial, but did not appear due to ill health. Motion on Behalf of Defendant Gustav Krupp von Bohlen for Postponement of the Trial as to Him (Nov. 4, 1945), reprinted in 1 IMT NUREMBERG, supra note 2, at 124. Krupp's son, Alfried, was ultimately tried and convicted of crimes against humanity at one of the later Nuremberg trials in 1947-48.

5. The Nuremberg Charter is appended to the London Agreement of August 8, 1945. Agreement by the Government of the United States of America, the Provisional Govemment of the French Republic, the Government of the United Kingdom of Great Britain and Northern Ireland, and the Government of the Union of Soviet Socialist Republics for the Prosecution and Punishment of Major War Criminals of the European Axis (Aug. 8, 1945), reprinted in 1 IMT NUREMBERG, supra note 2, at 8-16. "Criminal organizations" was intended to denote identifiable groups with voluntary membership, such as the Geheime Staatspolizei (Gestapo), the Schutzstaffeln der Nationalsozialistichen Deutschen Arbeiterpartei (SS), and most controversially, the German General Staff and High Command of the German Armed Forces. 
waging an illegal war, since the international community had outlawed aggressive war during the interwar era. The second count, alleging "war crimes," referenced violations of the traditional laws of war, such as battlefield atrocities and mistreatment of prisoners, as codified in international agreements such as the Hague and Geneva Conventions of 1907 and 1929.

The Nuremberg Charter defined the third and final count, of crimes against humanity, as:

murder, extermination, enslavement, deportation, and other inhuman acts committed against any civilian population, before or during the war; or persecutions on political, racial, or religious grounds ... in connection with any crime within the jurisdiction of the Tribunal, whether or not in violation of domestic law of the country where perpetrated. ${ }^{6}$

Crimes against humanity was the most innovative and controversial of the three counts. Its plain language suggested that it could be employed against the Nazis' mass atrocities against German Jews-a domestic, civilian populationgoing back to the early 1930s, before the outbreak of international armed conflict in 1939.

The Nuremberg Charter offered a concrete example of how the interaction among politics, ideas, and institutions pushed American diplomacy toward multilateral solutions as World War II drew to a close, even where such multiparty approaches imposed constraints or had awkward implications for the future projection of American power. The Charter was the product of a contentious drafting process. The two key issues under debate were, (1) could the charges be designed to assign individual guilt for the waging of aggressive war, in order to "establish the initiation of aggressive war as a crime under universally applicable international law," as one assistant prosecutor put it; and (2) would it be feasible, or indeed desirable, to prosecute pre-war anti-Jewish atrocities and harassment, even though these depredations were directed against a domestic population within Germany before the outbreak of war? ${ }^{7}$ Holding the leaders of a nation-state responsible for human rights-related transgressions-even atrocities as outrageous as those suffered by German Jews under the Nazi regime-could have uncomfortable implications for any country with a minority population that regularly endured harassment and discrimination.

The Charter's broad wording allowed the tribunal to answer in the affirmative to both of these questions-- "yes" to prosecuting individuals, and "yes" to a count capacious enough to include domestic and international crimes. However, while the tribunal agreed to criminalize aggression for individuals, it declined to hold the defendants responsible for pre-war atrocities against domestic populations, even though the Charter gave it the scope to do so.

6. Charter of the International Military Tribunal, art. 6, Aug. 8, 1945, 59 Stat. 1544, 1547, 82 U.N.T.S 279, 286-88 [hereinafter Nuremberg Charter] .

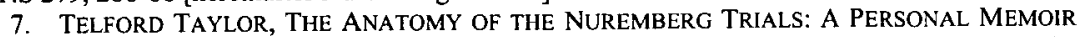
76 (1992). Taylor was an Assistant Prosecutor at Nuremberg and later the Chief Prosecutor of the "secondary" Nuremberg Trials. See supra note 2. 
Controversies over these issues were both internal, within the U.S. government, and external, among the Charter's signers-Britain, France, the U.S.S.R., and the United States.

Somewhat like the Atlantic Charter, the Nuremberg Charter was framed in general language and described fairly abstract guidelines. It was paired with a rambling sixty-seven page Indictment meant to apply the Charter's principles in a specific way to each individual defendant. The Indictment was diplomatically described by one of its authors as "a polygenetic document." 8 Opening with a virtually incoherent narrative of Germany's wartime transgressions, the Indictment cross-referenced the Charter provisions and then re-parsed the three charges into four, spelling out the alleged responsibility of each defendant. It concluded by listing each treaty or agreement alleged to have been violated by Germany's wartime leaders. ${ }^{9}$

For the ceremonial serving of the Nuremberg Charter and Indictment on the defendants, Major Neave's entourage included: the prison warden, Colonel Andrus; the General Secretary of the Tribunal, Harold B. Willey, who was on leave as the Chief Clerk of the United States Supreme Court; one of the two prison psychiatrists, Dr. Douglas M. Kelley; as well as an interpreter and two guards armed with revolvers and blackjacks. As Colonel Andrus opened the iron doors at the end of the low-ceilinged corridor connecting the court building to the prison wing, Neave intoned under his breath the beginning of the brief speech that Harold Willey had helped him draft the night before over Spanish brandies in the bar of the Grand Hotel: "I am Major Neave, the officer appointed by the International Military Tribunal to serve upon you a copy of the indictment in which you are named as defendant." 10

The former Nazi leaders were confined to separate cells on the ground floor of a three-tiered structure designed to accommodate about one hundred prisoners. ${ }^{11}$ Each thirteen-by-nine foot cell contained a steel bed bolted to the

8. TAYLOR, supra note 7, at 116. As Taylor delicately elaborated: "Flawless, the Indictment was not." Id. Taylor's characterization of the Indictment refers to the astonishing lack of coordination among that document's four drafting committees. Id. at 116-17. See also his description of the vicissitudes of the Indictment's drafting process. Id. at 79-118. The New Deal lawyer and former intelligence officer's main criticism concerned not so much the text of the Indictment itself, but rather his sense that the underlying "task of selecting the defendants was hastily and negligently discharged." Id. at 90. For example, he calls the confusion about indicting the ailing Gustav Krupp, and then the crude eleventh-hour attempts to substitute Gustav's son Alfried, as "a first-rate snafu." Id. at 92 .

9. Indictment, in 1 IMT NUREMBERG, supra note 2, at 27-92. As noted, twenty-four individual defendants were listed in the Indictment, but the industrialist Krupp was soon declared to be unfit; former leader of the Labor Front Robert Ley committed suicide; and Hitler's Deputy for Nazi Party Affairs, Martin Bormann, was never captured and was tried in absentia.

10. PERSONAL RECORD, supra note 1 , at 60,70 .

11. Nuremberg's Palace of Justice complex included a courthouse, an office building, and three prison wings, capable of accommodating a total of about 1,200 prisoners. The complex had formerly served as the Court of Appeals for the Nuremberg region. Somehow, it had evaded severe damage from the numerous Allied bombing sorties, which had all but leveled the rest of the old city. The main building filled two acres and comprised a dusty warren of "endless stone and marble corridors, mysterious nooks and crannies, and 650 rooms." Roughly half of the remaining cells were 
floor, a chair, a toilet, and a small, perpetually-open observation grille in the heavy oak door. As a precaution against suicide, the chair was removed at night, and its companion cardboard desk was designed to collapse if anyone were to stand on it; none of the furniture was allowed within four feet of the window wall.

After the Nazi labor leader Robert Ley nevertheless found a way to hang himself, the guard detail was quadrupled and a sentry was permanently stationed at each window, with instructions to shine a light on the defendant at night. The prisoners were ordered to sleep with their hands visible outside their bedding. ${ }^{12}$ Before the start of the trial, the defendants were allowed to talk to each other only during their twenty-minute exercise period in a grim and treeless courtyard. A wild-eyed Rudolf Hess's insistence on "goose-stepping" around the courtyard at exercise time enhanced the surreal quality of this environment. ${ }^{13}$

Colonel Andrus was the American Chief of Security at the Nuremberg prison, directing a staff of guards made up of extremely tough-looking and suspicious, gum-chewing American GIs who couldn't wait "to go home to Wisconsin and Cincinnati." 14 To raise morale, Andrus personally designed a flashy insignia for the guards' uniforms: a heraldic-looking shield of azure with a key at the top, symbolizing prison security, a rendering of the scales of justice in the center, and a broken Nazi eagle at the bottom. This insignia was painted on Andrus' helmet, to which the prison warden had applied layers of shellac to give it a high shine. Modeling his appearance on his idol and former

occupied by potential future defendants, including a number of women concentration camp guards, individuals detained for interrogation and as possible witnesses, as well as some ordinary German felons who were guarded by "Nazi wardens who had not yet been replaced." The courtroom for the Nuremberg trial was created by knocking down a wall between two of the twenty or so courtrooms on the second floor of the main building. Rooms were often commandeered for unofficial purposes, including American journalist Victor Bernstein's office, for which he made a facetious officiallooking placard reading "Ministry of Ruritania." ROBERT E. CONOT, JUSTICE AT NUREMBERG 21, 35, 60 (1983); PERSONAL RECORD, supra note 1, at 70, 77; Interview with Edith Simon Coliver, Nuremberg Interpreter (Apr. 24, 1998).

12. Ley, an alcoholic, had shredded his towel into a rope and attached it to the pipe above the toilet in his cell. See G.M. GILBERT, NUREMBERG DiaRY 8 (1947) [hereinafter NuREMBERG DIARY] (entry by prison psychologist); TAYLOR, supra note 7, at 132, 229-30; see also RONALD SMELSER, ROBERT LEY: HITLER'S LABOR FRONT LEADER (1988).

13. PERSONAL RECORD, supra note 1, at 45. Rudolf Hess, Hitler's deputy for Nazi Party matters, had famously flown himself across the English Channel in a stolen Messerschmidt on May 10,1941 and crash-landed in Scotland. Hess claimed he had undertaken his daring flight in order to broker a behind the scenes peace, after he became convinced that Germany's situation was hopeless. His story was discounted and he was confined to house arrest in Britain for four years before being tumed over to Allied captors at Nuremberg for trial. British lawyers and doctors advised the American warden that Hess was "as crazy as a Betsy bug." Hess insisted that the British had been trying to poison him and that he was unable to remember events more than two weeks in the past from any given present day. For more on Hess' assertions of memory loss, which he later recanted as fraudulent, see Psychiatrists' Report and accompanying Petition, in 1 IMT NUREMBERG, supra note 2, at 155-67; see also RoBERT G. STOREY, THE FINAL JUDGMENT? PEARL HARBOR TO NUREMBERG 141-46 (1968) (This idiosyncratic memoir by the U.S. Executive Trial Counsel and Document Chief at Nuremberg, although published in 1966, was compiled from notes taken at the time, according to its author.).

14. PERSONAL RECORD, supra note 1 , at 72 . 
commander, fellow cavalryman General George Patton, Andrus also often carried a leather riding crop. German inmate Hermann Goering, at one time Hitler's second in command, would sneeringly refer to Andrus as "the Fire Brigade Colonel," apparently a reference to the warden's shiny helmet. 15

The legendary vanity of Reichsmarschall Goering - "part Machiavelli, part Falstaff'-was of course more than a match for the self-regard of the comparatively lowly Colonel Andrus. ${ }^{16}$ Goering's titles since 1933 included President of the Reichstag, Reich Minister for Air, President of the Council of Ministers for the Defense of the Reich, Supreme Leader of the SA, General in the SS, Minister of the Interior of Prussia, Chief of the Prussian Police and the Prussian Secret State Police, Trustee of the Four Year Plan, head of the Hermann Goering Industrial Combine, Successor Designate to Hitler, and, for good measure, Germany's Chief Forester. Once the trial was under way, lacking a mirror in his cell, the fifty-three year old Goering would instruct his dark-suited defense counsel to stand behind the glass partition separating them during their consultations to make the glass more reflective so he could style his receding brown hair. ${ }^{17}$ Such vanity was not, apparently, entirely misplaced. Several weeks into the proceedings, women correspondents covering Nuremberg voted Goering their "overwhelming choice" as the defendant they would most like to sleep with. ${ }^{18}$

Having duly surrendered on V-E Day to the commander of the U.S. $36^{\text {th }}$ Infantry Division in the Austrian Alps, "Goering still believed that he would be treated like a captured emperor and confined to some convenient palace." 19 The Reichsmarschall was initially incarcerated with other top-ranking Nazis in an improvised detention center at the Palace Hotel, at Bad Mondorf, near the Luxembourg border. Hitler's former number-two man arrived at the detention center, code-named "Ashcan" by American service personnel, with a private valet, sixteen pieces of monogrammed ostrich-skin luggage, and a red hatbox in tow. Cached in the luggage was evidence of two of his more portable addictions: a trove of looted jewelry and over twenty thousand tablets of a "morphine substitute." 20 Goering was addicted and took forty of the pills a day. 21 The impression of a dissolute voluptuary-"infinitely corrupt... recall[ing] the madam of a brothel ... a sexual quiddity"- - was enhanced by his

15. See Joseph E. Persico, Nuremberg: Infamy on TrIal 57 (1994); Personal RECORD, supra note 1 , at 59, 70,76; see also TAYLOR, supra note 7 , at 230.

16. CONOT, supra note 11 , at $\mathrm{xi}$.

17. Eugene Davidson, The Trial of the Germans: An ACCOUNT of the Twenty-Two DEFENDANTS BEFORE THE INTERNATIONAL MILITARY TRIBUNAL AT NUREMBERG 59 (1966); see also G.M. Gilbert, Hermann Goering, Amiable Psychopath, 43 J. ABNORMAL \& SOC. PSYCHOL. 211 (1948).

18. Victor H. Bernstein, Final Judgment: THE Story of Nuremberg 3 (1947). Bernstein, an American journalist who covered the Nuremberg trial for the liberal New York newspaper $P M$, went on to observe dryly that "[t]he competition is not great, it is true." $I d$. at 4 .

19. PERSONAL RECORD, supra note 1 , at 73.

20. BURTON C. ANDRUS, THE INFAMOUS OF NUREMBERG 30-32 (1969).

21. Id. at 30 . 
red lacquered finger and toe-nails and the three hundred and forty pounds he carried on his five-foot-six inch frame. ${ }^{22}$ General Carl Spaatz, commander of the American Strategic Bombing Force, promptly threw a party for him, where the former World War I flying ace presented an autographed photograph of himself, inscribed: "War is like a football game, whoever loses gives his opponent his hand, and everything is forgotten."23

Given his initial handling, Goering was understandably slow to realize that the post-surrender exigencies of total war would be different, even for "gentlemen" officers and high-ranking political figures, than the aftermath of combat in the First World War. In that earlier conflict, as a flying ace in World War I and successor commander to Baron Manfred von Richthofen's legendary "flying circus," the young Hermann Goering would famously dip his wings to disabled opponents and fly on, rather than administer an unsporting coup de grace. $^{24}$

Goering most likely first became aware of this new post-surrender ethos at his interrogation in Augsburg in June 1945. At this session, U.S. General Alexander Patch, commander of the Seventh Army, unceremoniously demanded the Reichsmarschall's jeweled marshal's baton, inlaid with twenty golden eagles. "General, I can't give this to you," snapped Goering, offended by what he perceived as an impertinent request. "It is a symbol of my authority." "You have no more authority," came the sharp reply from Patch. "Hand it over!" Goering wrote promptly to General Eisenhower, as Supreme Commander of the Allied Forces in Europe, insisting that the baton be returned to him, and asking to keep his valet. Both requests were refused. ${ }^{25}$

Major Neave's first stop was at Goering's cell, where he served the Indictment and Charter on the former Reichsmarschall. Neave then handed Goering a third document, a list of names and addresses of German lawyers who might serve as defense counsel. Neave recalled feeling surprised that anyone in devastated Germany still had a home address. Judge Biddle and others had

22. Rebecca West, a Train of Powder: Six Reports on the Problem OF Guilt AND PUNISHMENT IN OUR TIME 6, 67 (1955); see PERSONAL RECORD, supra note 1, at 69-70. Colonel Andrus, who had also been the commandant of the Bad Mondorf prison, immediately put Goering on a diet and weaned him off his addiction to codeine. By the end of the trial, he had lost 160 pounds. United Press Wire Service, Goering Cured of Drugs as Trial Nears: In Perfect Health for Ordeal at Nuernberg, ROCKY MOUNTAIN NEWS, Sept. 8, 1945, at 2; STOREY, supra note 13, at 137, $139-40$.

23. CONOT, supra note 11, at 31-33.

24. Goering had been awarded the coveted Pour le Merite for his service in the First World War, Germany's highest wartime honor. See EDWIN P. HOYT, ANGELS OF DEATH: GoERING's LUFTWAFFE 34-36 (1994) ("The air war [in the First World War] was marked by gentlemanly, almost courtly, behavior on both sides."); see also PERSONAL RECORD, supra note 1, at 65-66; Alfred Kube, Herman Goering: Second Man in the Third Reich, in THE NAZI ELITE 62-71 (Ronald Smelser \& Rainer Zitelmann eds., Mary Fischer trans., 1993). Nor was this "courtliness" confined to the air war. See generally STANLEY WEINTRAUB, SILENT NIGHT: THE STORY OF THE WORLD WAR I CHRISTMAS TRUCE (2001).

25. HOYT, supra note 24, at 31-32; PERSICO, supra note 15, at 50-5I; PERSONAL RECORD, supra note 1 , at 73 . 
impressed upon Neave the importance of urging the defendants to choose defense counsel. ${ }^{26}$ Goering commented that he knew no one on the list, and asked if he could defend himself. "I think you would be well advised to be represented by someone," Neave persisted. Goering shrugged his shoulders. "It all seems pretty hopeless to me." He continued, "I must read this indictment very carefully, but I do not see how it can have any basis in law."

Goering next requested his own private interpreter, and Colonel Andrus reportedly could not suppress a smile at yet another request for special treatment. After Neave had left Goering's cell, Dr. Gustave M. Gilbert, the prison psychologist, asked the former Reichsmarshall to autograph a copy of the Indictment. Goering obliged-he was used to Americans asking for his autograph. He wrote, "The victor will always be the judge and the vanquished the accused." 27

The rather astonishing fact that Goering was even asked to "crystallize" his reactions to the Indictment by the prison psychologist- there were also two prison psychiatrists-highlights one pervasive American vision of the trial, as a kind of public social science experiment that would serve as a national therapy for the German people. In a delightful cross-cultural vignette, British Major Neave observed that "the two psychiatrists and the psychologist were essential to the American way of life at Nuremberg. They constantly interviewed the prisoners about the evidence against them." 28 He continued in this deadpan mode: "In the eccentric atmosphere of Nuremberg, they seemed to be necessary. They supplied learned reports about tensions, blocks and depressions regarded as necessary for understanding the Nazi mind." 29

Lieutenant Colonel Murray C. Bernays, the brilliant attorney and War Department official who drafted the original memo outlining the "conspiracy" theory for the trial and punishment of Nazi leadership, wrote in a June 1945 letter to his wife, "Not to try these beasts would be to miss the educational and

26. See Minutes of the Opening Session of the Tribunal, at Berlin (Oct. 18, 1945), reprinted in 1 IMT NUREMBERG, supra note 2, at 24-26 ("Notices will also be served upon [the defendants] in writing drawing their attention to Articles 16 and 23 of the Charter which provide that they may either conduct their own defense or be defended by any counsel professionally qualified .... [A] special clerk of the Tribunal [Major Neave] has been appointed to advise the defendants of their right and to take instructions from them personally as to their choice of counsel, and generally to see that the rights of defense are made known to them."). This preliminary session of the Tribunal had been held in Berlin as a sop to the Soviet delegation, which had unsuccessfully lobbied both for Berlin to serve as the seat of the entire proceedings and for the presidency of the Tribunal to rotate among the four judges. The Soviet representative on the Tribunal, Major General Ion Timifeevich Nikitchenko, an army judge advocate and Vice President of the Soviet Supreme Court, served as Tribunal President for this lone session in Berlin, while Lord Justice Lawrence, the British Judge, served as President for the duration of the actual trial in Nuremberg. See id. at 24; PERSONAL RECORD, supra note 1, at 74-75; TAYLOR, supra note 7, at 64-65, 98-99, 123-26.

27. "I asked each of the defendants to autograph my copy of the indictment with a brief statement giving his opinion of it" in order to "crystallize... [ $t$ ] heir first spontaneous reactions." NUREMBERG DIARY, supra note 12, at 4.

28. PERSONAL RECORD, supra note 1 , at 59.

29. Id. 
therapeutic opportunity of our generation."30 The defendants were considered to be singularly psychotic exemplars of a deeply disturbed dystopia, and discussion of their crimes was replete with imagery of disease and dementia. ${ }^{31}$

This sketch of Goering's initial incarceration captures several related themes of the Nuremberg trial as a legal, political, and even cultural event. The bizarre eccentricity of the atmosphere of the trial in the gutted provincial city was evoked most vividly by British author Rebecca West, whose three essays on the trial, originally published in the New Yorker, were collected in the volume $A$ Train of Powder. Of the British delegation, which numbered some 170 people, West wrote colorfully:

Anybody who wants to know what [the British] were like in Nuremberg need only read the early works of Rudyard Kipling. In villas set among the Bavarian pines, amid German modernist furniture, each piece of which seemed to have an enormous behind, a triple feat of reconstitution was performed: people who were in Germany pretended they were people in the jungle who were pretending they were in England. ${ }^{32}$

The hothouse atmosphere was further intensified by the overwhelming amount of work necessary to prepare and present the trial. "The entire preparatory work for the Nuremberg proceedings was attended by a kind of frenetic madness," writes Nuremberg chronicler Robert Conot, "as if the lunacy of the Nazi regime were a virus that had lingered in the atmosphere and infected those who had come to Germany."33

30. Letter from Murray C. Burnays to wife (June 10, 1945), cited in BraDLEY F. SMITH, THE AMERICAN ROAD TO NUREMBERG: THE DOCUMENTARY RECORD, 1944-1945, at 36 (1982) [hereinafter DOCUMENTARY RECORD]; see also Memorandum, Trial of European War Criminals, from Murray C. Burnays (Sept. 15, 1944), reprinted in id. at 34 . Bernays, whose legal ideas are discussed below, was a nephew by marriage of Sigmund Freud.

31. For example, " $[\mathrm{t}]$ he Nazis were maniacs who plastered history with the cruelty which is a waste product of man's moral nature, as maniacs on a smaller scale plaster their bodies and their clothes with their excreta." WEST, supra note 22 , at 69 . This kind of language, in tum, is remarkable for how reminiscent it is of Nazi language about the role of Jews in German society. See, for example, entries relating to Nazi propagandist and former Gauleiter of Nuremberg, Julius Streicher, in NUREMBERG DIARY, supra note 12, at 9-10, 38, 41, 73-74, 117, 125-26. For a more sensationalist treatment, see for example RANDALL L. BYTWERK, JULIUS STREICHER: NAZI EDITOR OF THE NOTORIOUS ANTI-SEMITIC NEWSPAPER DER STURMER (2001).

32. WEST, supra note 22 , at 9 . The French and Soviet delegations were smaller than the British one; but note that the American delegation numbered over 600 people, including 150 lawyers, and totaled well over a thousand counting the military personnel. Telephone Directory, International Military Trials, Nürnberg, December 1945, Katharine B. Fite Letters, HSTPL [hereinafter Fite Letters]; see TAYLOR, supra note 7, at 213; CONOT, supra note 11, at 60 . Assistant Prosecutor Taylor has also described what he saw as the "colonialism" of the atmosphere of the Nuremberg enclave, an evanescent international community of judges, lawyers, interpreters, secretaries, journalists, military officials of all ranks, a local German population, and, of course, the defendants themselves, with a smattering of visiting VIPs thrown in for good measure. TAYLOR, supra note 7 , at 208 . West explained that among the Allied forces at all levels, "eccentrics ... were replacing the more normal types as they were demobilized." WEST, supra note 22 , at 33 . Note that West spent only the equivalent of about two weeks at the year-long trial. Nevertheless, her evocative accounts of the trial's atmosphere are unsurpassed.

33. CONOT, supra note 11 , at 58 . Katharine Fite, a State Department lawyer specializing in "Nazi criminality" at Nuremberg, educated at Vassar and Yale Law School, wrote to her parents about how "we are in a wild rush with briefs due a week from tomorrow .... I don't see how we can 
Once the trial was underway, however, Nuremberg rapidly became something of "a citadel of boredom" for its foreign visitors, and in the grip of the "extreme tedium" of the year-long assize, there was a pronounced tendency for residents of the Nuremberg enclave to drink excessively. One young American interpreter ascribed the pervasive loosening of peacetime standards of personal conduct to "a very strange mentality, the mentality of the conquerors." 34 Indeed, Neave concluded that, for the Soviet contingent especially, frequent "public drunkenness was part of the Nuremberg scene. It was intended to express the triumph of the Soviet peoples over Hitler and bid defiance to bourgeois convention." 35

Beyond these quotidian factors, part of Nuremberg's eccentric atmosphere was linked to the trial's anomalous position as an event on the cusp of the transition from war to peace. The Palace of Justice was situated in the heart of a bomb-blasted Nuremberg, where the stench of the thirty thousand dead entombed in its ubiquitous rubble was still pervasive. This location emphasized what a reversion the trial experience was to wartime conditions, as did the idiosyncratic security measures imposed by the American prison staff. ${ }^{36}$ The trial staff nevertheless saw themselves as striving to lay the juridical groundwork for a future peace. As West put it in a stark metaphor:

A machine was running down, a great machine, the greatest machine that has ever been created: the war machine .... It was a hard machine to operate; it was the natural desire of all who served it, save those rare creatures, the born soldiers, that

be ready for the 20th ... . [W] are carrying the mammoth share." Letter from Katharine Fite to parents (Nov. 3, 1945), Fite Letters, supra note 32. Assistant prosecutor Taylor similarly wrote of the frenetic madness of the trial's preparatory work. See TAYLOR, supra note 7, at 174.

34. Edith Simon Coliver, a Nuremberg interpreter and German-Jewish refugee who emigrated to the United States as a child and graduated from the University of California at Berkeley in 1944, described how she and other Nuremberg colleagues freely "liberated" desirable items such as clocks and books from the German households where they were billeted. She remembered wishing she could swipe Goering's braid-trimmed hat as a souvenir. Simon discussed another pervasive practice at Nuremberg, also described by Rebecca West, namely how cadres of middleaged married men, who tended to populate the more senior echelons of the Nuremberg community, were notorious for seeking comfort in the arms of various female members of the administrative staff and press corps, many of whom were young and single. (Both Simon and West spoke from personal experience: Simon had an affair with Victor Bernstein, a married American joumalist twenty-one years her senior; she ghostwrote large portions of his book, Final Judgment: The Story of Nuremberg. See BERNSTEIN, supra note 18. West had an affair with Francis Biddle, former U.S. Attorney General and the American judge at Nuremberg.) Interview with Edith Simon Coliver, supra note 11; Edith Helga Simon, Judgment Day: Justice: My Trip to the Nuremberg Trials, 9, 16, 26-27 (unpublished manuscript, on file with the author) [hereinafter Simon Diary] (entries for Oct. 21, 1945; Oct. 27, 1945; Nov. 10, 1945; and Nov. 12, 1945); WEST, supra note 22, at 13-14; TAYLOR, supra note 7, at 547 .

35. PERSONAL RECORD, supra note 1 , at 54

36. For example, the ever-vigilant Colonel Andrus had noticed that one of the so-called "VIP" observers in the gallery "had crossed her ankles and was showing her shins and a line of petticoat, and he conceived that this might upset the sex-starved defendants, thus underestimating both the length of time it takes for a woman to become a VIP and the degree of the defendants' preoccupations. But, out of a further complication of delicacy, he forbade both men and women to cross their ankles.... These rules were the subject of general mirth in Nuremberg" where “eccentricity prevailed." WEST, supra note 22 , at $43-44$; see also id. at 10,45 . 
it should becoine scrap. There was another machine which was warming up: the peace machine, by which mankind lives its life .... All over the world people were sick with impatience because they were bound to the machine that was running down, and they wanted to be among the operators of the machine that was warming up. ${ }^{37}$

This vignette offers a window into the immediate cultural context of the trial, as an event that was both forward- and backward-looking. In seeking a more nuanced picture of the troubled legitimacy of the trial and its charter, this study analyzes the proceedings as an example of what some legal scholars and political scientists call "transitional justice" - an event simultaneously marking the end of the war and attempting to lay useful juridical groundwork for the peace. One premise of this study is that legal ideas cannot be analyzed in a vacuum, divorced from the context and texture of even the most ordinary events. To the contrary, the details of context-both world-historical and quotidian-are essential for understanding the highly contingent and "eccentric" world of the Nuremberg Charter.

II.

THREE CONTEXTS FOR NUREMBERG: "THE HARD FACTS OF DEFEAT AND OF THE NEED FOR POLITICAL, ECONOMIC AND SOCIAL REORIENTATION MUST BE THE TEACHERS OF THE GERMAN PEOPLE"

The Charter of the Nuremberg trial lies at the intersection of three different sets of contexts in the international law and relations of the postwar world. The first was the political question of how the Allies sought to handle defeated Germany as a whole. Key legal issues at the Nuremberg trial, such as individual accountability, were implicated in a broader Allied policy debate over reparations, disarmament, and, especially, "denazification"-the reeducation and rehabilitation of ordinary Germans and their leaders. One perspective on Nuremberg is thus to view it as part of the political history of the treatment of defeated states in wartime.

The second relevant context for the trial is the development of its legal ideas. In the field of public international law, the Nuremberg Charter was attempting to accomplish three goals at once. First, it sought to crystallize preexisting trends in international law regarding the outlawry of aggressive war, especially regarding individual responsibility for violations of this emerging norm. Second, the trial sought to herald landmark innovations in law such as charges for mass atrocities, itemized in the charter as "crimes against humanity." Third and finally, the Charter was a treaty in its own right, consolidating and building on traditional treaty law regarding the laws of war. ${ }^{38}$ Nuremberg had

37. Id. at 11 .

38. Political scientist Gary Bass has argued compellingly that the term "crimes against humanity" was first formulated as an indictable offense at the abortive 1920 British-run courts martial of so-called Young Turks for massacres of Armenians in 1915. GARY JONATHAN BASS, Stay the Hand of Vengeance: The Politics of War Crimes Tribunals 106-08 (2000). However, none of the preparatory legal memos I have reviewed for the Nuremberg Charter mention 
many architects, and they differed over the relative priorities of these legal ideals. Examining this intellectual context draws particularly on the legacy of World War I-era developments in ideas about international law and organization.

The third important context for Nuremberg is institutional. The trial was intended to play a significant role in a wider postwar international order of multilateral organizations. Many contemporaries saw it as a first step on a road to a permanent International Criminal Court. The contours of the Nuremberg Charter emerged from a series of informal negotiations at the San Francisco Conference of June 1945, itself convened to finalize the United Nations Charter. The Nuremberg Charter, the United Nations Charter, and the Bretton Woods Charters collectively embodied the ideology of the Atlantic Charter declaration of war and peace aims. ${ }^{39}$ The architects of Nuremberg saw themselves as contributing to a new, integrated idea of "security," encompassing all four of President Roosevelt's so-called Four Freedoms. ${ }^{40}$ Together with proposals for comprehensive disarmament, Nuremberg was designed primarily to be about freedom from the fear of aggressive war.

Most of the existing literature about Nuremberg either fails to develop or misconstrues at least one of these three contexts. As a result, previous treatments tend to be organized around a rather sterile debate about whether the trial was "good law" or "just politics." To some critics, Nuremberg was either "the most majestic forensic drama ever enacted on the stage of History" 4 albeit with what assistant prosecutor Telford Taylor conceded were a few

this precedent (including the British materials), and Bass notes as much in his own analysis of Nuremberg. It seems more likely that the Nuremberg legal advisors believed they were deriving the term directly from the so-called Martens clause of the Fourth Hague Convention of 1907, which invoked "the principles of the law of nations, as they result from the usages established among civilized peoples, from the laws of humanity, and the dictates of the public conscience." Convention (IV) Respecting the Laws and Customs of War on Land, Oct. 18, 1907, Preamble, 36 Stat. 2277, 2280, 1 Bevans 631, 633 [hereinafter Fourth Hague Convention].

39. The "Atlantic Charter ideology" might be summarized as (1) updated Wilsonian ideals, such as self-determination, disarmament, and international organization; (2) so-called Four Freedoms ideals, including the rhetorical flourish that "all the men in all the lands may live out their lives in freedom from fear and want," with its suggestion that individuals might have a direct relationship with some kind of supra-national legal order; and (3) anti-imperial, free trade provisions.

40. The "Four Freedoms" were freedoms of speech and of religion, and freedoms from fear and want. Franklin D. Roosevelt, Annual Message to Congress (Jan. 6, 1941), reprinted in [1940] The PUBlic PAPERS AND ADDRESSES OF FRANKLIN D. RoOSEVElt 672 (Samuel I. Rosenman ed., 1941) [hereinafter PPA]. Together with the Atlantic Charter, the so-called Four Freedoms were part of a constant refrain of U.S. wartime propaganda regarding war aims and postwar aspirations, both within the United States and internationally. See, e.g., OFFICE OF WAR INFORMATION, TEXTES DE LA LIBERTÉ DECLARATIONS OFFICIELLES FAITES AU COURS DE L'HISTOIRE DES ÉTATS-UNIS (1944) (featuring "Les Quatres Libertés" and "La Charte de l'Atlantique"); N. BEN-HORIM, THE AMERICAN SOLDIER'S MORAL GUIDE (1943) ("as endorsed by the War Department and the Vice-President," and including both the Atlantic Charter and the Four Freedoms speech among its seven reprinted documents).

41. J.H. MORGan, THE GREAT ASSIZE: AN EXAMINATION OF THE LAW OF THE NUREMBERG TRIALS 1 (1948). 
"political warts",42 — or it was, to many others, a cynical power play, a product of "pseudo-legalized vindictive retribution."43 Of course, these quotations capture two colorfully expressed extremes. Yet even the more sophisticated and dispassionate assessments of Nuremberg's legitimacy tend to be organized around the question of how "legal" the proceedings really were. By contrast, this study analyzes the underlying sources of Nuremberg's legitimacy from political, legal, and institutional perspectives. Such an approach portrays Nuremberg in historical context, as a projection of a peculiarly American, New Deal-style approach to problem solving onto the international stage. It is also suggestive of the strong relationship American approaches to international institutions have to domestic political culture.

\section{III. \\ HANDLING DEFEATED GERMANY}

"Dear Winston," wrote President Franklin Roosevelt to Prime Minister Churchill in February of 1944, "I have been worrying a good deal of late on account of the tendency of all of us to prepare for future events in such detail that we may be letting ourselves in for trouble when the time arrives." 44 The president was objecting to "detailed instructions and appendices" regarding planning for the postwar world in general, and the prospective defeat of Germany in particular, which he regarded "as prophecies by prophets who cannot be infallible." 45 FDR continued, "Now comes this business of what to do when we get into Germany. I understand that your Staff presented a long and comprehensive document .... My people over here believe that a short document of surrender terms should be adopted [instead] that would conform more to "general principles.", 46

One of the lessons 1940s American policymakers had drawn from the planning experience of the First World War might be summarized as "do not wait until the war is over to plan the peace." This insight had been mined from the ordeal of Woodrow Wilson in Paris, where the American president had been walled-in by pre-existing secret agreements among the European allies. ${ }^{47}$ Yet many students of FDR's decision-making style have noted that Roosevelt's usual response to bureaucratic controversy "was almost invariably to procrastinate, usually by either promising all things to all parties or by openly

42. TAYLOR, supra note 7, at 639.

43. John GaNGE, AMERICAN Foreign Relations: PERMANENT PRoblems and Changing POLICIES 258 (1959).

44. Letter from Franklin Roosevelt to Winston Churchill (Feb. 29, 1944), reprinted in U.S DEP'T OF STATE, [1944] 1 FOREIGN RELATIONS OF THE UNITED STATES: GENERAL 188 (1966).

45. Id.

46. Id. at 189 .

47. See Herbert HoOVER, The ORdeal of WOOdRow WILSON 191-92 (1958); see also JOHN MILTON COOPER, JR., BREAKING THE HEART OF THE WORLD: WOODROW WILSON AND THE FIGHT FOR THE LEAGUE OF NATIONS (2001). 
putting off any decision." 48 The cabinet's push for prior planning accordingly tended to produce proposals that were quite abstract and general, often based on competing philosophies. Combined with the Rooseveltian tendency to back-off in the face of controversy, the resulting directives were largely determined by the negotiating skills and agendas of second- and third-tier administration officials.

Bureaucratic controversy in great abundance confronted Roosevelt in late ' 1944 and early 1945 around the initial post-surrender plans for Germany. This debate distilled into three competing approaches. First, State Department planners advocated an economically sound and self-supporting Germany as essential to the economic rehabilitation of Western Europe and as a bulwark against communism. The State Department's post-surrender planning memos embodied Secretary Hull's longstanding approach of emphasizing economic issues, especially trade. This emphasis continued even after the ailing Hull's resignation three weeks after the November 1944 election. ${ }^{49}$

Second, the War Department, under the venerable Republican Henry L. Stimson, focused on the immediate problems of administering the postwar occupation of Germany. The War Department's "Handbook of Military Government," circulated in late August of 1944, emphasized relying on existing authority structures within Germany to maintain order. The Handbook's avowedly short-term approach would likely have longer-term ramifications, favoring a "soft peace." 50 The third approach to denazification was centered in the Treasury Department, under New Dealer and Roosevelt confidant Henry Morgenthau, Jr. The Treasury approach aimed at eliminating a future resurgence of German militarism and aggression by demolishing Germany's military and industrial capabilities, and by imposing policies aimed at thoroughgoing social and even psychological reform. 51

Historians have ascribed the vehemence of these disputes within the Executive branch to a variety of factors, such as differences in the ideology or organizational culture of the various departments, personality clashes among the respective cabinet members, or strains and uncertainties in their personal

48. Warren F. Kimball, Swords or Ploughshares? The Morgenthau Plan for DEFEATED NAZI GERMANY, 1943-1946, at 44 (1976).

49. Although Hull had indicated to FDR that he wished to retire earlier, the president had prevailed on his longest-serving Cabinet member to stay on until at least until after the election. Hull's resignation was accordingly announced on November 27 . He was succeeded by Edward R. Stettinius, Jr., first as Acting Secretary and then as Secretary. DEAN ACHESON, PRESENT AT THE CREATION: MY YEARS IN THE STATE DEPARTMENT 87 (1969).

50. War Department Handbook of Military Government for Germany (Aug. 1944), attached to Morgenthau's Memorandum for the President, August 25, 1944, in Presidential Diaries Files, Morgenthau Papers, FDRPL, 1394-96 [hereinafter Morgenthau Papers]; see also Memorandum from Franklin D. Roosevelt to Henry Stimson, Secretary of War (Aug. 26, 1944) (noting that "[t]his socalled 'Handbook' is pretty bad"); SUBCOMM. TO INVESTIGATE THE ADMIN. OF THE INTERNAL SEC. ACT \& OTHER INTERNAL SEC. LAWS, COMM. ON THE Judiciary, 90TH CONG., 1 MORGENTHAu Diary (Germany) 443 (Comm. Print 1967) [hereinafter MORGENTHAU Diary].

51. See generally HENRY MORgENTHAU, JR., GERMANY IS OUR PROBLEM xi-xiii (1945); KIMBALL, supra note 48 , at 4. 
relationships with Roosevelt. Later commentators have tended to emphasize the personal social attitudes and background of the cabinet members, as well: Stimson's patrician anti-semitism, for instance, or Morgenthau's German-Jewish heritage. The case of Treasury Secretary Morgenthau, however, illustrates the dangers of armchair psychologizing about motives. Morgenthau's views about the "pastoralization" of Germany - the term was actually Churchill's-and the peace-loving virtues of the yeoman farmer were just as likely to be the result of the Treasury Secretary's background as a gentleman farmer who idealized Jeffersonian values as to have anything to do with his ethnic background. Also, Roosevelt often expressed complete accord with Morgenthau's outlook on the treatment of defeated Germany, particularly the aspect of focusing on a cultural transformation of the German people as a whole, rather than exclusively on the Nazi party. 52

The press and public opinion played a pivotal role in how these Cabinetlevel disputes played out. Debate over the postwar treatment of Germany spilled over into an acrimonious public dispute shortly after Roosevelt publicly supported the Treasury Department's approach at the Quebec Conference of September 1944. Together with Churchill, FDR approved a version of the socalled "Morgenthau Plan" for the treatment of post-surrender Germany. ${ }^{53}$ The proposal emphasized social and educational reforms to effect a "reform of the German character," to be complemented by complete disarmament, deportations of Nazi Party officials to help rebuild the countries they had devastated, and the partition of industrial areas of the country into internationalized zones so they could no longer serve as "the caldron of wars." 54

Although the vast majority of accused war criminals were to be tried, a top layer of "arch-criminals" was to be summarily executed by Allied firing squads upon capture and identification. In the autumn of 1944, Roosevelt himself favored summary execution quite explicitly. An aide's notes of a September 9 , 1944 conversation indicate that "[w]ar criminals, the President hoped[,] might be dealt with summarily. His principal preoccupation was that they be properly identified before being disposed of, but he expressed himself as very much opposed to long, drawn-out legal procedure." 55

52. Even after publicly backing away from Morgenthau's approach as the 1944 election neared, Roosevelt still encouraged the Treasury Secretary privately, even urging him to write a book on the subject. In his forthcoming biography of Henry Stimson, Sean Malloy argues that FDR's support was so wholehearted that the so-called "Morgenthau Plan" should more accurately be known as the "Roosevelt-Morgenthau Plan." Sean Malloy, The Reluctant Warrior: Henry L. Stimson and the Crisis of 'Industrial Civilization' (2002) (unpublished Ph.D. dissertation, Stanford University) (on file with author); see generally MORGENTHAU, supra note 51.

53. U.S. Treasury Dep't, Program to Prevent Germany from Starting a World War III (Sept. 9, 1944), reprinted in U.S. STATE DEP'T, [1944] FOREIGN RELATIONS OF THE UNITED STATES: THE CONFERENCE AT QUEBEC 131-40 (1972) [hereinafter FRUS QUEBEC]; see also Memorandum, Suggested Post-Surrender Policy for Germany, from Henry Morgenthau to Franklin Roosevelt (Sept. $5,1944)$, reprinted in id. at 101-06.

54. Memorandum from Henry Morgenthau to Franklin Roosevelt, supra note 53, at 101-06.

55. Robert Murphy, Memorandum of Conversation with President Roosevelt (Sept. 9, 1944), in Papers of Robert Murphy, Roosevelt File, Box 52, Hoover Institution Archives [hereinafter 
The Morgenthau Plan shared a certain reformist sensibility with the New Deal. Morgenthau explained for a popular audience how, "[I]n discussions of what to do with Germany, she has been compared to a mental patient, a problem child case of retarded development, a young girl led astray, a slab of molten metal ready for the molder and much else besides."56 These similies, Morgenthau explained, merely emphasized how thoroughgoing was "the educational or evolutionary problem that must be faced." 57 The Treasury program concluded that, "[t]he hard facts of defeat and of the need for political, economic and social reorientation must be the teachers of the German people."58

As Roosevelt historian Warren Kimball argues, Morgenthau's approach was part and parcel of "the belief of many New Dealers in the efficacy of grand plans as the solution to problems" and it assumed "that an entire nation could be restructured and redirected by outside agents." 59 Morgenthau even used New Deal parlance and analogies in some of his diary entries when discussing plans for German reeducation. Referring to Germans over the age of 20 who had been thoroughly inculcated with Nazi ideology, he wrote, "I am convinced that you could change them [although] you may even have to transplant them out of Germany to some place in Central Africa where you can do some big TVA project. $" 60$

Privately, Secretary of War Henry Stimson muttered that the Treasury Department's plan was "Semitism gone wild for vengeance." 61 His public response was much more canny, however. The day after the Quebec Conference, Stimson sent an influential memo to Roosevelt, arguing that the Treasury program violated American principles, and explicitly invoked the 1941 Atlantic Charter. ${ }^{62}$ The Secretary of War asserted that "the proposed treatment

Murphy Papers] (Robert Murphy was a State Department official who later became the political and diplomatic advisor to General Lucius D. Clay, chief administrator of the U.S. Occupation Zone in post-surrender Germany); see also JOHN MORTON BLUM, FROM THE MORGENTHAU DIARIES, YEARS OF WAR, 1941-1945, at 397 (1967) (diary entry for September 2, 1944).

56. MORGENTHAU, supra note 51 , at 144 .

57. Id.

58. FRUS QUEBEC, supra note 53, at 137-38.

59. KIMBALL, supra note 48 , at 31 . Note that the premise of a thoroughgoing restructuring of society by outside agents was in fact largely realized in the case of the U.S. Occupation of Japan. See generally JOHN W. DOWER, EMBRACING DEFEAT: JAPAN IN THE WAKE OF WORLD WAR II (1999).

60. BLUM, supra note 55, at 353 (quoting Morgenthau diary entry for Sept. 2, 1944). The "TVA" was the Tennessee Valley Authority, one of the most ambitious public works programs of the New Deal

61. Diaries of Henry L. Stimson (microfilm edition), Green Library, Stanford University, original in Manuscripts and Archives Division, Sterling Memorial Library, Yale University (entry for Sept. 16-17, 1944). Stimson was likely the first to refer to Morgenthau's approach as "Carthaginian," an adjective that clung to the plan thereafter, and was an evocation of John Maynard Keynes' assessment of the peace provisions of the First World War in Keynes's 1920 Economic Consequences of the Peace. Id.; see also JOHN MAYNARD KEYNES, THE ECONOMIC CONSEQUENCES OF THE PEACE (1920). Surprisingly little has been published on Secretary Stimson, a lawyer, statesman, and pillar of the Republican establishment who joined the Roosevelt administration in 1940. Sean Malloy offers a detailed and nuanced account in his forthcoming Reluctant Warrior, supra note 52.

62. Memorandum from Stimson to Roosevelt (Sept. 15, 1944), reprinted in FRUS QUEBEC, 
of Germany would, if successful, deliberately deprive many millions of people of the right to freedom from want and freedom from fear." 63 Stimson pointedly reminded Roosevelt that "under the Atlantic Charter victors and vanquished alike are entitled to freedom from economic want."64 He elaborated that it would be "a crime against civilization" to force poverty on the "educated, efficient, and imaginative" German people. ${ }^{65}$ Perhaps coincidentally, the controversy simultaneously leaked from an Administration source to allies in the press, Drew Pearson and Arthur Krock of the New York Times. ${ }^{66}$

Stimson's approach was really a shorter-term version of the equally conciliatory State Department approach, and was favored by officials at the State Department such as the young George Kennan, then serving as an aide to John Winant, ambassador to Britain. Kennan opposed even the mildest denazification programs as eliminating "the people upon whom Germany had to depend for future leadership" and as likely to promote "disharmony."67 Stimson and his assistant secretary, John J. McCloy, insisted that their plans were focused only on establishing law, order, and efficiency. ${ }^{68}$ Irate Treasury Department staff responded that the complementary War Department and State Department approaches were predicated on the Allies' assuming responsibility for the quality of life in Germany. The inevitable result would be a higher standard of living among the defeated Germans than in the hard-bitten Allied European nations, which had sacrificed so much for victory.

Morgenthau's approach was actually a rather close approximation of American public opinion in the autumn of 1944. A Gallup poll released in November 1944, for instance, showed that 34 percent of Americans wanted to destroy Germany as a political entity, 32 percent wanted continuing supervision and control over Germany, and 12 percent wanted to "rehabilitate" Germany. 69 After the cabinet controversy was leaked to the press, however, public opinion began to shift, and the Treasury proposals never again regained the initiative.

The dynamics of this shift had several components, and illustrate the

supra note 53 , at $482-85$.

63. Id. at 484 .

64. Id. at $483-84$

65. Id. at 483 .

66. Drew Pearson broke the story on September 21, 1944. See Drew Pearson, Morgenthau Plan on Germany Splits Cabinet Committee, N.Y. TIMES, Sept. 24, 1944, at 1, 8. There is some debate about whether the leaker was Stimson himself, Cordell Hull, or James F. Byrnes. See, e.g., KIMBALL, supra note 48 , at 41,43 (suggesting it was most likely Byrnes). Historian Steven Casey believes that it was most likely Hull, while political scientist Gary Bass seems to find the circumstantial case against Stimson to be more than suggestive. STEVEN CASEY, CAUTIOUS Crusade: Franklin D. RoOSEvelt, american Public OPINION, AND the WaR AGainst Nazi GERMANY 183 (2001); BASS, supra note 38, at 168-69. Stimson biographer Sean Malloy believes that the leaker was unlikely to have been Stimson personally, but could have been a War Department subordinate such as John J. McCloy.

67. GEORGE F. KENNAN, MEMOIRS, 1925-1950, at 175 (1967)

68. Id.

69. [1935-48] I THE GALLUP POLL: PUBLIC OPINION 1935-1972, at 426, 460, 463, 470, 472

(George H. Gallup ed., 1972). 
complex workings obscured by the label of "public opinion" in mid-1940s America. ${ }^{70}$ In the wake of the initial New York Times coverage, the influential Wall Street Journal and then the nationally syndicated Associated Press quickly took up the Morgenthau story. ${ }^{71}$ Newspapers across the political spectrum were soon concurring with the Washington Post's assessment that the Morgenthau plan was "the product of a feverish mind from which all sense of reality had fled." 72 The Treasury plan would ensure that Germany remained "a festering sore ... in the heart of Europe, and there would be installed a chaos which would assuredly end in war."73 The Post further emphasized that Nazi propaganda minister Josef Goebbels was already using the story "as a threat to spur Germans to greater resistance against the Allies." 74

Indeed, the American press was running stories about the Morgenthau controversy in parallel columns with stories of a serious Allied setback around Arnheim, in the lower Rhine, due to a rallying of German resistance. Commentators at the time emphasized the coincidence. By the end of September, legislators on Capitol Hill were attacking the Treasury Department approach, and the White House was receiving quantities of unfavorable mail. "Prior to the announcement [of the Morgenthau Plan]," noted Senator Edwin Johnson, "the Germans were surrendering in droves; now they are fighting like demons." 75

With the presidential election seven weeks away, an embattled and annoyed Roosevelt withdrew his support for the Treasury proposal, favoring the "middle road" of the short-term War Department approach almost by 'default. The president fired off a memo to the Secretary of State:

Somebody has been talking not only out of turn to the papers or on facts which are not fundamentally true.

No one wants to make Germany a wholly agricultural nation again, and yet somebody down the line has handed this out to the press. I wish we could catch and chastise him. ${ }^{76}$

70. The material in this paragraph and the next closely follow the excellent analysis of American public opinion in CASEY, supra note 66 , at $184-87$, which also guided me to useful sources. I thank Susan Ferber, editor with Oxford University Press, for calling my attention to Casey's important work.

71. Arthur Krock, Why Secretary Morgenthau Went to Quebec, N.Y. TIMES, Sept. 22, 1944; Alfred F. Flynn, Post-War Germany, WALL ST. J., Sept. 23, 1944. Steven Casey notes that "[t]he AP article was a page-one lead story on September 24 in a number of papers, including Baltimore Sun, Chicago Tribune, New York Herald Tribune, and Washington Evening Star." CASEY, supra note 66, at 263-64 n.8.

72. Editorial, Samson in the Temple, WASH. PosT, Sept. 26, 1944.

73. Id.; see also Editorial, Morgenthau's Plans for Germany, WASH. TIMES-HERALD, Sept. 26, 1944; The German Industrial Machine, PM, Sept. 27, 1944.

74. Germans Are Aroused by Morgenthau Proposal, WASH. POST, Sept. 26, 1944.

75. Ted Lewis, Morgenthau Plan Blamed for Stiffening of Nazis, WASH. TIMES-HERALD, Sept. 30, 1944 (quoting Senator Edwin Johnson); see also Ernest Lindley, Future of Germany: Reaction to the Morgenthau Plan, WASH. POST, Sept. 29, 1944. On presidential mail, see Casey's assessment in CASEY, supra note 66 , at 186-87.

76. Franklin D. Roosevelt, Memorandum for the Secretary of State (Sept. 29, 1944), in Murphy Papers, supra note 55. As late as October 20, 1944, the President forwarded a memo to the 
The aggregate term "public opinion" is a shorthand caption for this dynamic relationship of activist public officials, press leaks, down-to-the wire electioneering, journalistic editorializing, and congressional and citizens' advocacy for their favored interpretations of public events. Astonishingly, several treatments of the demise of the Morgenthau Plan do not even mention the impending U.S. presidential election. In saying that the Treasury Department's approach was defeated by public opinion, it is important to examine why decision-makers might have been especially sensitive to such opinion. A more richly contextualized approach brings the relationship of ideas and events into sharper focus.

The British and even the Soviet leadership never took a particularly hard line about post-surrender partition, deindustrialization, or summary execution of war criminals in Germany, although they favored all three policies at one time or another. For example, at the Teheran Conference of December 1943, Stalin famously remarked to Churchill at a formal dinner that between 50,000 and 100,000 Germans ought to be summarily executed. Roosevelt apparently tried to turn the comment into a joke by counterproposing that only 49,000 members of the German General Staff be executed. ${ }^{77}$ The British and the Soviets were more concerned about extension of Lend Lease loans and about arrangements for Eastern Europe, respectively. (In historian Warren Kimball's quaintly gendered terms, "Conflicts between the Americans and the British were more on the order of family quarrels; quarrels which could, if necessary, be resolved almost peremptorily by the Americans - the breadwinner.") ${ }^{78}$ Uncertainty still reigned among the so-called Big Three even as late as the February 1945 Yalta Conference, just two months before Roosevelt's death.

A statement released for public consumption at Yalta is worth quoting at length because it still lies so very close to the Morgenthau approach: "It is our inflexible purpose to destroy German militarism and Nazism and to ensure that Germany will never again be able to disturb the peace of the world," the Yalta statement began. ${ }^{79}$ It continued:

Secretary of State arguing that, as regards "the treatment of Germany ... speed on these matters is not essential at the present moment .... I dislike making detailed plans for a country which we do not yet occupy." Franklin D. Roosevelt, Memorandum for the Secretary of State (Oct. 20, 1944), in Murphy Papers, supra note 55

77. See Minutes of Tripartite Political Meeting (Dec. 1, 1943), reprinted in U.S. STATE DEP'T, [1943] FOREIGN RELATIONS OF THE UNITED STATES: THE CONFERENCES AT CAIRO AND TEHRAN 602-04 (1961). But note that all the major-decision makers, including Stalin, at one time or another also supported trials. See, for example, Excerpts from a Telegram sent by Prime Minister Churchill to the President, Telegram No. 801 (Oct. 22, 1944), in Murphy Papers, supra note 55, where Churchill notes:

On major war criminals Uncle Joe [Stalin] took an unexpected ultra-respectable line. There must be no executions without trial otherwise the world would say that we were afraid to try them. I pointed out the difficulties in international law but he replied that if there were no trials there must be no death sentences but only life-long confinements.

78. KIMBALL, supra note 48 , at 17.

79. Report of the Crimea Conference (Feb. 11, 1945), reprinted in U.S. STATE DEP'T, [1945] FOREIGN RELATIONS OF THE UNITED STATES: THE CONFERENCE AT YALTA AND MALTA 970 (1955) 
We are determined to disarm and disband all German armed forces; break up for all time the German General Staff that has repeatedly contrived the resurgence of German militarism; remove or destroy all German military equipment; eliminate or control all German industry that could be used for military production; bring all war criminals to just and swift punishment and exact reparation in kind for the destruction wrought by the Germans; wipe out the Nazi party, Nazi laws, organizations and institutions, remove all Nazi and militarist influences from public office and from the cultural and economic life of the German people; and take in harmony such other measures in Germany as may be necessary to the future peace and safety of the world. 80

The main difference between this Yalta statement and the thrust of the original Treasury Department proposal was that the Yalta language explicitly distinguished between Nazis and the German people. This distinction is underlined by the concluding sentence of the Yalta statement on war criminals: "It is not our purpose to destroy the people of Germany, but only when Nazism and Militarism have been extirpated will there be hope for a decent life for Germans, and a place for them in the comity of nations." 81 This distinction, between Nazis and Germans, was one that FDR consistently refused to make himself, however. Roosevelt often expressed his opinion "that all Germans, and not just the Nazis, were guilty of aggression and crimes against humanity." The president added numerous handwritten notes to his own copy of the Treasury Department plan aimed at the cultural reform of ordinary Germans, including a proposed prohibition on the "goose step" march. ${ }^{82}$

Even the most basic outlines of Allied denazification policy remained ambiguous until after Roosevelt's death. In May 1945, officials in charge of implementing these policies soon found themselves at sea among overlapping committees. General Lucius Clay, soon to be put in charge of the American sector of a quadripartite Allied Control Authority (Britain, France, the U.S.S.R., and the U.S.) for the administration of Occupied Germany, lamented the proliferating post-surrender bureaucracy. In a letter to a War Department official, Clay saw a bumpy ride ahead for more ambitious Allied approaches to multilateralism. "We understand here that consideration is being given to separate Commissions for Restitutions, for the Trial of War Criminals, for the Internationalization of the Ruhr and for other purposes," he wrote resignedly. ${ }^{83}$

[hereinafter FRUS YALTA].

80. Id at $970-71$. In addition, parallel secret protocols, not released until years later, apparently envisioned a dismemberment almost as thoroughgoing as that in the Treasury Department proposal, along with high reparations. Confidential provisions reprinted as Protocol of the Proceedings of the Crimea Conference (Feb. 11, 1945), in id. at 978-79.

81. Id.

82. KIMBALL, supra note 48, at xiv; Robert Murphy, Memorandum of Conversation with President Roosevelt (Sept. 9, 1944), in Murphy Papers, supra note 55; Henry Morgenthau, Memorandum of Conversation with President Roosevelt (Aug. 19, 1944), in Morgenthau Papers, supra note 50, at 1386-88; see also Memorandum of Conversation with Roosevelt and State Department Officials, reprinted in U.S. STATE DEP'T, [1943] 1 FOREIGN RELATIONS OF THE UNITED STATES DIPLOMATIC PAPERS: GENERAL 542 (1963) [hereinafter FRUS 1943].

83. General Lucius D. Clay to General John Hilldring, Director of the War Department's Civil Affairs Division (May 7, 1945), reprinted in 1 THE PAPERS OF GENERAL LUCIUS D. CLAY: 
Administering these occupied areas was a kind of microcosm for broader cooperative projects: "We are going to face many difficulties in making the Allied Control Authority work. To me it seems clear that if it doesn't work we might as well throw the idea of a United Nations out the window." 84

By the early spring of 1945 , the State Department position had prevailed on questions of economic policy, that is, against dismemberment and deindustrialization and in favor of the rapid rebuilding of productive resources as a bulwark against communism. The moderate positions of the War Department won out on political, legal, and administrative questions, including policies relating to the treatment of war criminals. In sum, the Allies had three options for handling high-ranking Axis authorities as part of implementing their "unconditional surrender" policy. ${ }^{85}$ They could deal with leading war crimes suspects by executive fiat (which would have involved shooting them upon identification, as per the Morgenthau plan, or confining them in political imprisonment); they could let them go free under an amnesty policy; or they could put them on trial.

All three choices were problematic. Summary execution without trial would have been ideologically awkward for the democracies in light of the Allies' contemporaneous pronouncements on the nascent United Nations and the rule of law. A widely-publicized pronouncement from the Yalta Declaration linked multilateral action on war crimes to the principles of the 1941 Atlantic Charter itself:

By this declaration we affirm our faith in the principles of the Atlantic Charter, our pledge in the [1942] Declaration by the United Nations, and our determination to build in cooperation with other peace-loving nations a world order under law, dedicated to peace, security, freedom and the general well-being of mankind. ${ }^{86}$

The Allies rejected as politically unworkable the option of confinement in a remote area by executive fiat, along the lines of the "Elba solution" for Napoleon. ${ }^{87}$ And given the rhetoric (and reality) of Nazi leaders as enemies of

GERMANY, 1945-1949, at 12 (Jean Edward Smith ed., 1974).

84. Id.; see also LUCIUS D. ClAY, DECISION IN GERMANY (1950); Lucius D. Clay, Proconsul of a People, by Another People, for Both Peoples, in AMERICANS AS PROCONSULS: UNITED STATES MILITARY GOVERNMENT IN GERMANY AND IN JAPAN, 1944-1952, at 103-13 (Robert D. Wolfe ed., 1984); see generally JOHN H. BACKER, WINDS OF HISTORY: THE GERMAN YEARS OF LUCIUS DUBIGNON CLAY (1983) (detailing General Clay's role as the U.S. Military Governor of Germany during American postwar occupation).

85. Roosevelt had called for the "unconditional surrender" of the Axis regimes at a January 24,1943 , press conference in the wake of the Casablanca Conference with Churchill. See RoBERT DALLEK, FRANKLIN D. ROOSEVELT AND AMERICAN FOREIGN POLICY, 1932-1945, at 373-76 (1979); see, e.g., Brian L. Villa, The U.S. Army, Unconditional Surrender, and the Potsdam Proclamation, 6 J. OF AM. HIST. 92 (1976). For the legal implications of unconditional surrender, see the discussion below on the drafting of the Nuremberg Charter.

86. FRUS YALTA, supra note 79 , at 971 .

87. Former U.S. Secretary of State Henry Kissinger wrote approvingly of Tsar Alexander of Russia's decision to banish Napolean to Elba. In Kissinger's estimation, the Tsar and his fellow architects of the Concert of Europe system successfully "resisted the temptation of a punitive peace. This may have been due to the very quality which is usually considered their greatest failing: their 
civilization, granting any kind of outright amnesty was never seriously considered either, as it ran the risk of seeming to imply that the sacrifices of millions of Allied soldiers and civilians had been in vain. As with the resonant phrases of the Atlantic Charter-resonant because they echoed with people's aspirations and in turn helped shape their expectations-Allied leaders found themselves constrained by their own propaganda and rhetoric. Ambiguous public pronouncements on the future treatment of war criminals, as well as the Atlantic Charter's own language that its terms would apply to both victor and vanquished, had already contributed to a vision of the future that proved difficult simply to abandon. ${ }^{88}$

An important perspective on the ensuing legal disputes over what to do with war criminals is thus to see them primarily as diplomatic donnybrooks, microcosms of this wider denazification debate, rather than as debates over the intrinsic merits of abstract legal theories. One might argue that, at least as regards the symbolic role of the Nuremberg defendants as surrogates for wider groups of Nazis in German society, the Nuremberg trial itself could be portrayed as a vestigial and largely symbolic embodiment of the Morgenthau Plan, with its focus on "reform of the German character." 89 The choice to stage a high-profile trial for selected Nazi leaders can best be understood when set in this context of possible alternative approaches.

IV.

TRANSLATING IDEAS ABOUT INTERNATIONAL LAW INTO ACTION

The ideas about international law embodied in the Nuremberg Charter were a new combination of older conceptions regarding just and unjust wars, mixed with positivist ideas about traditional crimes of war that had been codified by previous treaties. These precedents were then combined with innovative arguments about the scope of a "living" international customary law, through an

indifference to popular pressures." HENRY A. KISSINGER, A WORLD RESTORED: METTERNICH, CAstlereagh AND the Problems of PEACE 1812-22, at 139 (1957). Napoleon escaped from his initial banishment and was not truly exiled until he was dispatched to St. Helena. See, e.g., HENRY HOUSSAYE, 1815: LA PREMIERE RESTAURATION, LE RETOUR DE L'îlE D'ELBE, LES CENT JOURS (1911); see also Charles K. WeBster, THE Foreign POLICY OF CASTlereagh, 1812-1815: BRITAIN AND THE RECONSTRUCTION OF EUROPE 479 (1931); C.K. WEBSTER, THE CONGRESS OF VIENNA 136-37 (1919). Webster, a professor of international history, served as a member of the British delegation to the Dumbarton Oaks Conversations in the summer of 1944 . His 1919 monograph on the Congress of Vienna had been officially commissioned by the British delegation to the Paris Peace negotiations, for which Webster also served as a delegate, "in the hope that knowledge of 1814-15 would save the peacemakers of 1918-19 from misjudgments or errors" made by their predecessors; but Webster admitted in the 1930s that "the monograph had no observable effect whatsoever." P.A. REYNOLDS \& E.J. HughES, THE Historian AS DiPlomat: Charles KINGSLEY WEBSTER AND THE UNITED NATIONS, 1939-1946, at 2 (1976).

88. See Gary Bass' argument about how domestic norms in liberal states also constrain international action. BASS, supra note 38 , at 21-23.

89. See the opening section of this article, discussing the American vision of Nuremberg as a "national social science experiment." See also MORGENTHAU, supra note 51 (Morgenthau's own defense of his approach written with Roosevelt's encouragement for a popular audience.). 
analogy to the growth of Anglo-American common law. The precise contours of this synthesis can only be explained as a political negotiation. ${ }^{90}$ Yet the negotiators and their aides saw themselves as harnessing the pre-existing legitimacy of persuasive legal precedents in order to create something new.

The Nuremberg trial and its Charter were designed to mark "the reestablishment of the principle that there are just and unjust wars and that unjust wars are illegal," in the words of the chief American negotiator of the Nuremberg Charter, Supreme Court Justice Robert H. Jackson, who would later serve as the U.S. Chief Prosecutor. ${ }^{91}$ In his June 1945 Report to the President on "Atrocities and War Crimes," Jackson explained:

Doubtless what appeals to men of good will and common sense as the crime which comprehends all lesser crimes is the crime of making unjustifiable war. War necessarily is a calculated series of killings, of destructions of property, of oppressions. Such acts unquestionably would be criminal except that International Law throws a mantle of protection around acts which otherwise would be crimes, when committed in pursuit of legitimate warfare.

The Report concluded that if the underlying conflict were an illegitimate use of force, however, this mantle of protection would be removed, and the killings, destructions, and oppressions would revert to their normal status as ordinary crimes. 93

The Jackson Report's reasoning captures the Nuremberg Charter's conception of a war crime, as a label referring to an act which remained criminal even though committed in time of war, and which presupposed the existence of laws of war. The whole concept of "civilized warfare" rested on the assumption that the ravages of battle ought to be mitigated as far as possible by prohibiting needless cruelties. The practice of regulating the conduct of war can be traced to the emergence of knightly chivalry in Europe, and back before that to the jus fetiale of ancient Rome. ${ }^{94}$

The early Christian conception of a war crime was linked to the moral

90. A later section of this article summarizes some of the political maneuvering around finalizing the contours of the Nuremberg Charter, but note that this story is well told in a variety of secondary sources, both scholarly and popular. See, e.g., ARIEH J. KochavI, PRELUDE to NuREMBERG: ALLIED WAR CRIMES POLICY AND THE QUESTION OF PUNISHMENT (1998); CONOT, supra note 11; ANN TUSA \& JOHN TUSA, THE NUREMBERG TRIAL (1983); DOCUMENTARY RECORD, supra note 30 . See also accounts by participants, such as TAYLOR, supra note 7 , at 78-118, and Sydney S. Alderman, Negotiating the Nuremberg Trial Agreements, 1945, in NEGOTIATING WITH THE RUSSIANS (Raymond Dennet \& Joseph E. Johnson eds., 1951). See also PETER CALVOCORESSI, NUREMBERG: THE FACTS, THE LAW, AND THE CONSEQUENCES (1947).

91. ROBERT H. JACKSON, REPORT OF ROBERT H. JACKSON, UNITED STATES REPRESENTATIVE TO THE INTERNATIONAL CONFERENCE ON MILITARY TRIALS 6 (1949) [hereinafter REPORT OF ROBERT H. JACKSON].

92. Id. at 8 .

93. Id. at 9 .

94. The jus fetiale constituted a part of the unwritten law of the Roman Constitution whereby a special group of priests would determine whether a foreign nation had waged unjust warfare against the Romans. See, e.g., ARTHUR NuSSBAUM, A CONCISE HISTORY OF THE LAW OF NATIONS 17 (1947); see also COLEMAN PHILlipson, 2 THE INTERNATIONAL LAW AND Custom of ANCIENT GREECE AND ROME 315-48 (1911). 
status of the conflict as a whole-whether it was just or unjust. Theologians such as Saint Augustine (354-430), Saint Thomas Aquinas (1225-1274) and Francisco Suarez (1548-1617), as well as jurists such as Hugo Grotius (15831645), were largely concerned, in their writings that touched on the laws of war, with establishing criteria for just and unjust wars. They tended to concur that the situations that might justify forcible resistance were the defense of life, property, or of a third party unjustly attacked. ${ }^{95}$

As the temper of international law became increasingly laicized during the course of the $18^{\text {th }}$ century, this moralistic just war tradition, known as the jus ad bellum, came to be overshadowed by a more pragmatic, rule-oriented vision of warfare in which the state of war itself was assumed to be a neutral context for actions which could be subject to regulation (the jus in bello). The Hague Conventions' central premise is that " $[t]$ he right of belligerents to adopt means of injuring the enemy is not unlimited." 96 The aftermath of the First World War encouraged a revival of the moralistic tradition of folding the jus in bello into the jus ad bellum, as part of the wider agenda of outlawing aggressive war. The two concepts, in practice never entirely distinct, became increasingly intertwined.

This trend was particularly pronounced in the war-torn countries of Allied Europe, largely because of the general public's moral outrage at widelypublicized atrocities from World War I such as the execution of British nurse Edith Cavell, the destruction of French and Belgian towns such as Lille and Louvain by rampaging German troops, the Zeppelin bombing of British cities, and civilian deaths from German U-boat attacks on the high seas. ${ }^{97}$ At the 1919 Paris Peace Conference, British prime minister Lloyd George and French premier Georges Clemenceau had insisted that war crimes be the very first agenda item at the Conference's first official session. ${ }^{98}$ An official commission of fifteen prominent international lawyers took up this question, and concluded

95. See, for example, St. Augustine's assessment that, while every war is lamentable, particular kinds of wrongs suffered at the hands of adversaries resulted in "the necessity of waging just wars." ST. Augustine, De Civitate Dei ConTRA PAGANos 150-51 (W. Greene trans., 1960); see also St. ThOMAS AQUinAS, SuMMA THEOLOGIAE 80-83 (Blackfriars 1965); Francisco SuAREZ, SElECTIONS FROM THREE WORKS, DE TRIPLICI VIRTUTE THEOlOGIA: ChARITATE 817 (G. Williams trans., 1944); HUGo GROTIUS, DE JURE BELli AC PACIS 565-66 (F. Kelsey trans., 1925). This note and the following one, and the accompanying text, are drawn from my article, Elizabeth $\mathrm{S}$. Borgwardt, Ideology and International Law: The Dissent of the Indian Justice at the Tokyo War Crimes Trial (1991), reprinted in 2 WAR CRIMES LAW 145-213 (Gerry Simpson ed., 2004). 48.

96. See Fourth Hague Convention, supra note 38, art. 22, 36 Stat. at 2301, 1 Bevans at 647-

97. See, e.g., Ebba Dahlin, French and German Public Opinion on Declared War Aims, 1914-1918, in IV HISTORY, ECONOMICS, AND POLITICAL SCIENCE, 193-341 (1933); PIERRE MIQUEL, LA PAIX DE VERSAILLES ET L'OPINION PUBLIQUE FRANÇAISE (1972). See also political scientist James F. Willis's excellent monograph, JAMES F. WILlIS, ProloguE To NUREMBERG: THE POLITICS AND DIPLOMACY OF PUNISHING WAR CRIMINALS OF THE FIRST WORLD WAR 27-28 (1982).

98. Council of Ten Meeting (Jan. 17, 1919), reprinted in U.S. DEP'T OF STATE, [1919] 3 Foreign RELATIONS of THE UNITED STATES, PARIS PEACE CONFERENCE 169 (1943) [hereinafter FRUS PARIS]. 
two months later that the Central Powers had "premeditated" the war. 99 A subcommittee of this group then recommended that "for the future, penal sanctions should be provided for such outrages."100 In other words, the commission determined that Germany should be held responsible, not just for violations of specific laws regarding the conduct of the war, but for the very state of war itself.

Yet the phrase "for the future" is quite telling as well, expressing the legalist hesitations of the Commission's chair, U.S. Secretary of State Robert Lansing. Lansing and the other American member of the Commission, international legal scholar James Brown Scott, refused to sign the Commission's report. They submitted a minority report objecting to the proposal to treat as grounds for legal liability "violations of the laws of humanity, as to which there was no fixed and universal standard, but it varied with time, place, circumstance and conscience of the individual judge." The American duo also doubted the feasibility of pursuing penal sanctions because of the "difficulty of finding whether the act was in reality one of aggression or defense."101 Gary Bass explains succinctly that these legalist objections "were not based on a lack of faith in law, but on an excess of it"- a positivist rigidity born of a direct generalization of domestic legal standards to the international level. ${ }^{102}$

Popular pressure played a large role in these developments, as shown by Lloyd George's 1918 election year cry that "[t]he Kaiser must be prosecuted." 103 The prime minister's election polemic continued; "The war was a hideous, abominable crime, a crime which has sent millions of the best young men of Europe to death and mutilation, and which has plunged myriads of

99. INT'L Law Div., Carnegie ENDOWment For INT'L PEaCe, Pamphlet No. 32, VIOLATIONS OF THE LAWS AND CUSTOMS OF WAR: REPORT OF THE MAJORITY AND DISSENTING REPORTS OF THE AMERICAN AND JAPANESE MEMBERS OF THE COMMISSION ON RESPONSIBILITIES AT THE CONFERENCE OF PARIS, 1919, at 18-21 (1919).

100. Id. at 22-23.

101. Id. at 58; see also James Brown Scott, The Trial of the Kaiser, in WHAT REALLY Happened at Paris: The Story of THE Peace Conference, 1918-1919, at 231-58 (Edward M. House \& Charles Seymour eds., 1921). Interestingly, Lansing does not mention his minority report in his own memoir, RoBert LANSING, THE PEACE NEgOtIATIONS: A PERSONAL MEMOIR 33 (1921). Before becoming Secretary of State in 1914, Lansing had "had one of the largest private practices in international law in the United States and had participated in more international arbitrations than any other American," while Professor Scott had served as a U.S. delegate to the Second Hague Peace Conference of 1907. WILLIS, supra note 97, at 69.

102. BASS, supra note 38 , at 59. I use the term legalism here following Judith Shklar's definition of legalism as "rule-oriented thinking." Bass, however, sometimes uses legalism as a synonym for idealism. The result is that under Bass's analysis, the legalist position favored trying the defeated Germans. By contrast, I see the anti-trial arguments of Lansing and Scott as better expressing Shklar's (and my) conception of legalism-i.e., subjecting the Kaiser to trial would necessitate too many innovations and disruptions to established expectations, and so legalists such as Lansing and Scott opposed it. On legalism as idealism, see GEORGE F. KENNAN, AMERICAN DIPLOMACY, 1900-1950, at 95 (1953).

103. David Lloyd George Speech (Nov. 29, 1918), in TimEs (London), Nov. 30, 1918, at 6. Lloyd George denied ever saying "Hang the Kaiser!" but the popular election slogan has been widely attributed to him. See DAvid LloYd GeORGE, I MEMOIRS OF THE PEACE CONFERENCE 109 (1939). 
homes into desolation. Is no one responsible? Is no one to be called to account?" 104

Article 227 of the Treaty of Versailles explicitly provided that "a special tribunal will be constituted to try [German Kaiser Wilhelm II] . . . [It] will be guided by the highest motives of international policy, with a view to vindicating the solemn obligations of international undertakings and the validity of international morality." 105 The Allied plan proved abortive, however, because the Kaiser fled to the Netherlands, which refused to surrender him for trial. ${ }^{106}$ Some of the putative backup plans for addressing the Kaiser's act of impunity seemed to have been drawn from the libretto of a comic opera. None was successfully implemented, including a proposal that the British government officially urge him to commit suicide; plans for banishment to less comfortable venues such as Chile, Java, and the Falkland Islands, presumably after a kidnapping; and an actual abduction attempt by a team of American veterans led by Colonel Luke Lea, former senator and publisher of the Nashville Tennessean. ${ }^{107}$ Encouraged by his advisors to feign illness in order to garner public sympathy, the former monarch bought a castle twenty-five miles from the German border where he lived in comfortable exile until his death from old age in 1941.

Article 228 of the Versailles Treaty called for prosecution of those Germans who had "committed acts in violation of the laws and customs of war."108 Belgium, France, Britain, and Italy each produced a list of suspects, totaling about 3,000 names. Even allowing for group arraignments for crews of particular U-boats or staffs of individual POW camps, these numbers still suggested close to a thousand separate trials. ${ }^{109}$ By 1920 , British politicians in

104. Lloyd George, supra note 103.

105. Treaty of Peace Between the Allied and Associated Powers of Germany, June 28, 1919 , art. 227, 225 C.T.S. 188, 285, 2 Bevans 43, 136-37 [hereinafter Treaty of Versailles]; see also Quincy Wright, The Legal Liability of the Kaiser, 13 AM. POL. SCI. REV. 120-28 (1919).

106. The Netherlands had an "immemorial tradition" of sheltering asylum-seekers. WILLIS, supra note 97, at 67 (internal quotation omitted); see also ALAN PALMER, THE KAISER: WARLORD OF THE SECOND REICH 212-13 (1978).

107. After concluding that their planned abduction would not succeed due to a bridge that was unexpectedly washed out at a strategic point, the self-appointed group of American commandos: determined to persuade the kaiser to go with them voluntarily to face his accusers manfully. They continued on to the [kaiser's] estate on the night of January 5 [1919], bluffed their way inside the house, and demanded to see Wilhelm II. After a two-hour standoff, during which the kaiser refused to meet with the Americans, Dutch troops surrounded the estate with spotlights and machine guns, forcing Colonel Lea and his men to depart.

WILLIS, supra note 97, at 101; see also T. H. Alexander, They Tried to Kidnap the Kaiser and Brought Back an Ash Tray, SATURDAY EVENING POST, Oct., 23, 1937, at 5. See BASS, supra note 38 , at 77-78, for a summary of the even less-plausible alternative plans. 86.

108. Treaty of Versailles, supra note 105, art. 228, 225 C.T.S. at 285-86, 2 Bevans at 285-

109. See British, French, and Italian Meeting, Paris (Jan. 15, 1920), reprinted in DOCUMENTS ON BRITISH FOREIGN POLICY, 1919, at 886. An important part of Bass's thesis is what he calls the " rough mathematical ratio of wartime suffering," namely, that for victorious countries in World Wars I and II, "[t]heir passion for war crimes trials matched their relative death tolls," with Belgium and France leading the pack in the wake of World War 1 , followed by Britain and Italy. 
particular were worrying about the destabilizing effects of so many trials on Germany's shaky Weimar government, particularly where suspects would need to be handed over to an Allied tribunal by the already unpopular German authorities. "To try very large numbers," according to meeting minutes paraphrasing Lloyd George, "would be to create great difficulties for the German Government, which he believed to be better than either a Bolshevist Government or a Militarist Government." 110 Perhaps it would be better to try to prosecute a smaller number, just to "make an example."111

The United States, as an Associated rather than an Allied power, had not submitted a list of suspected criminals. President Wilson, in particular, felt that the war crimes provisions of the Versailles Treaty were a "weak spot" in that agreement, and distracted from the more important work of the League of Nations in establishing the rule of law worldwide. ${ }^{112}$ Even after the joint Allied list was boiled down to just over 400 defendants, plans for trials under the socalled "war guilt" clauses of the Treaty of Versailles served as flashpoints for popular resentment in Germany. 113 In 1920, German Chancellor Hermann Müller approved a secret fund to pay the expenses of the defendants, while German diplomats in Paris warned that no police force in Germany would be willing to execute the warrants. ${ }^{114}$ Confronting these difficulties, the Allies reluctantly accepted a German suggestion to try forty or so suspects before the German Supreme Court (Reichsgericht) sitting at Leipzig, in a series of test cases grouped by the victims' country of origin. 115

By the time the trials got underway, in May 1921, several suspects had mysteriously escaped. Others who stood trial received sentences of less than a year, or escaped from jail, while their wardens received public congratulations. Still other defendants, including some accused of torturing Belgian children, were acquitted completely, usually on the grounds that they were only following orders. ${ }^{116}$ French and Belgian witnesses withdrew from Leipzig in protest amid jeering German crowds. In 1922, France sought to impose sanctions under the

BASs, supra note 38 , at 58, 78. For Bass, this shows how closely calls for war crimes trials were allied to political acts of vengeance. By contrast, Bass argues that the fact that the United States proved to be an exception to this rule in the World War II era-as a supporter of trials that had not endured occupation or widespread civilian casualties - demonstrates the power of a competing norm of American legalism instead of political vengeance. Id. at 58.

110. Notes of a Meeting of the Heads of Delegations of the Five Great Powers (Sept. 15, 1919), reprinted in 8 FRUS PARIS, supra note 98, at 214

111. Id.

112. See Notes of a Meeting Held at President Wilson's Home (May 5, 1919), reprinted in 5 FRUS PARIS, supra note 98, at 470-71; see generally ERNEST R. MAY, THE WORLD WAR AND AMERICAN ISOLATION, 1914-1917, at 40-41 (1959).

113. See, e.g., WILLIS, supra note 97 , at 137 .

114. See BASS, supra note 38 , at 89 .

115. Bass notes how the breakdown of even this small number of test cases was "proportionate to Allied suffering: sixteen from the Belgian list, eleven from the French, seven British, five Italian, and four from smaller countries." Id. at 80 .

116. See id. at 81, 89; see also Editorial, Convicting Itself, N.Y. TIMES, July 9, 1921 ("[T]hus the German mentality is shown to be unaltered: and the proposed punishment of war criminals is a farce."). 
Treaty of Versailles, in large part over German non-compliance on war crimes provisions, and in early 1923, France reoccupied the Ruhr to protest violations of additional articles of the Versailles treaty. 117

Continuing Allied demands for legitimate trials produced widespread protest demonstrations in Germany, while public celebrations greeted German Chancellor Josef Wirth's announcement in 1922 that no further suspects would stand trial. The dashing young flying ace Hermann Goering attended one of these protest meetings and was particularly impressed by one of the speakers he heard there. After the electrifying speech ended, the decorated war hero Goering made a point of introducing himself to the rumpled and sweaty speaker, Adolf Hitler. ${ }^{118}$ Alexander Cadogan, later to serve as the British permanent undersecretary for foreign affairs during World War II, was already a foreign office official during the First World War. Commenting on the Leipzig trials, Cadogan concluded tersely that the "experiment has been pronounced a failure." 119

In the interwar era, a number of diplomatic efforts attempted to reassert the moralistic principle of the jus ad bellum, whether the underlying conflict was "just" or not. The Covenant of the League of Nations asserted that governments could wage war unjustly. ${ }^{120}$ Using war as an instrument of policy meant the aggressive or discretionary use of armed force; a defensive use of force was still understood as a justified response to attack. The 1925 Locarno treaties banned aggression among their signatories, ${ }^{121}$ and the 1928 Pact of Paris also explicitly condemned war. ${ }^{122}$ After 1928 , "war was no longer to be the source and subject of legal rights, and in that sense became an illegal thing," argued a 1946 article in the South Atlantic Quarterly, further asserting that "[a]n aggressor and a victim were no longer equals under international law." 23 By implication, then, legal rights in wartime could become dependent, at least in part, on the side for which one fought, with the aggressor responsible, not just for individual atrocities, but also for the state of war itself.

The Nuremberg approach was an innovation in the world of legal ideas, but the trial's design was also an attempt to learn from the history of the failure of the World War I-era approaches. In the wake of the First World War, the

117. See, e.g., W. M. Jordan, GREat Britain, France AND THE GERMAN Problem, 1918 -

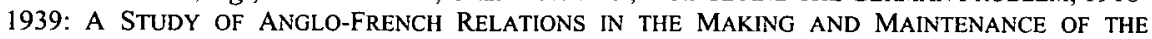
VERSAILLES SETTLEMENT 70-71 (1943).

118. WILLIS, supra note 97 , at 141 .

119. BASS, supra note 38, at 81 (quoting British Foreign Office, FO 371/7529/ C17096, Allied-German Negotiations on War Criminals, Dec. 9, 1922).

120. The Covenant of the League of Nations, June 28, 1919, art. 16, in 13 AM. J. INT'L L. 128, 134-35 (Supp. 1935).

121. Treaty of Mutual Guarantee Between Germany, Belgium, France, Great Britain, and Italy, Oct. 16, 1925, 54 L.N.T.S. 289.

122. General Treaty Providing for the Renunciation of War as an Instrument of National Policy, Aug. 27, 1928, 46 Stat. 2343, 94 L.N.T.S. 57.

123. Willard N. Hogan, War Criminals, 45 S. ATLANTIC Q. 418 (1946). This quotation echoes the discussion in chapter 3 of Henry L. Stimson's position on the illegality of aggressive war in the interwar era. 
legalistic power of positivism had eclipsed more moralistic "just war" conceptions when it came to the trial and punishment of Germany's wartime leaders. To Nuremberg's critics, the revival of the just war framework suggested another, and in their view more alarming, corollary: that victims of such illegal aggression could now be presumed to have virtually unlimited rights, including the right to resort to atomic weapons. ${ }^{124}$ To Nuremberg's proponents, however, the development of the Nuremberg Charter was simply a search for a pragmatic, New Deal-style middle way that could support a conception of the progressive development of international law, while avoiding the pitfalls of the past.

At a November 1943 meeting in Moscow between the chief foreign affairs officers of the Big Three, the Allies called for the punishment of those who later came to be known as "conventional" war criminals-"those who have been responsible for, or who have taken a consenting part in . . atrocities, massacres, and executions." 125 Significantly, the leading diplomats then officially broadened the term to include "[t]he major criminals, whose offences have no particular geographical localisation." 126 Whatever the meaning of this phrase, it signaled that the Allies would be enlisting legal ideas regarding wartime culpability as part of their larger postwar policy edifice.

The 1943 Moscow Declaration is the traditional departure point for many accounts of the negotiation of the Nuremberg Charter, mainly because the jurists assembling in London in the summer of 1945 described their task as implementing the Moscow Declaration. ${ }^{127}$ Moscow was not the first high-level evocation of Axis criminality, however. Earlier examples included a 1942 statement by Roosevelt, noting that "the time will come when [perpetrators of atrocities] shall have to stand in courts of law in the very countries which they are now oppressing and answer for their acts." 128 In January 1942, the nine

124. The Indian judge at the 1946-48 Tokyo Trial of defeated Japanese leaders, Rhadbinod Pal, made this point with particular poignancy in a fascinating 1,235 page dissent (the published version, of 735 pages, was illustrated with photographs of atomic destruction). See RHADBINOD PAL, INTERNATIONAL MILITARY TRIBUNAL FOR THE FAR EAST: DISSENTIENT JUDGMENT 38-40 (1953). More recent critics, notably the international legal scholar Richard Falk, have pointed to what Falk calls "the irony of August 8, 1945," the day of the signing of the London Agreement, containing the Nuremberg Charter. Richard A. Falk, Forty Years After the Nuremberg and Tokyo Tribunals: The Impact of the War Crimes Trials on International and National Law: Remarks by Richard A. Falk, 80 AM. SOC'Y INT'L L. PROC. 65 (1986). As Falk explains it, "on the very day the Allies were sitting down to sign the London Charter, one of their members was engaged in what in retrospect may be the most notable act of criminality committed during at least the international phases of the war: the atomic bombing of Nagasaki." Id. See also the headlines on the front page of the New York Times for August 9, 1945, where "4 Powers Call Aggression Crime in Accord Covering War Trials" competes unsuccessfully for space with "Atom Bomb Loosed on Nagasaki."

125. Anglo-Soviet-American Conference, Declaration on General Security (1943), reprinted in U.S. DEP'T OF STATE PUB. No. 2423, ThE AXIS IN DEFEAT: A COLlECTION OF DOCUMENTS ON AMERICAN POLICY TOWARD GERMANY AND JAPAN 4 (1945) [hereinafter Moscow Declaration]

126. Id.; see also U.S. Dep't of State, Declaration of German Atrocities, 9 DEP'T ST. BULL. 311 (1943); CORDEll HUll, 2 The Memoirs OF CORDELl Hull 1289-91 (1948).

127. See Nuremberg Charter, supra note 6, Preamble, 59 Stat. at 1544, 82 U.N.T.S at 280.

128. [1942] PPA, supra note 40, at 330. 
governments in exile in London issued the Inter-Allied Declaration of St. James's Palace, asserting that they would "place among their principal war aims the punishment, through the channel of organized justice, of those guilty and responsible for these [war] crimes, whether they have ordered them, perpetrated them, or in any way participated in them." 129

The Declaration of St. James's also repudiated the idea that perpetrators of atrocities against civilians could be properly punished by "acts of vengeance on the part of the general public." The signers relied on "the sense of justice of the civilized world" for their authority. ${ }^{130}$ One product of this Declaration was the establishment of a United Nations War Crimes Commission (UNWCC) in London in October 1943, an evidence-gathering organ that specifically excluded Holocaust-related atrocities from its purview. The Soviet Union, although a victim of massive German atrocities, refused to participate in the UNWCC, complaining that the commission was dominated by former British colonies. This London-based War Crimes Commission was not under American control either, and one of the factors shaping U.S. war crimes policies throughout 1944 was the effort to fend off unwelcome proposals by the UNWCC as that organization became more assertive.

Warning statements to Germany before late 1944 were likely deliberately framed in rather vague terms in order to avoid creating a propaganda tool that might stiffen Axis resistance. Nevertheless, fear of reprisals cannot alone explain the astonishingly perfunctory public discussion of Axis atrocities in 1942, 1943, and throughout most of 1944. Prime Minister Churchill, for instance, believed that Allied threats about inevitable future punishments might actually discourage atrocities, if they served to "make some of these villains reluctant to be mixed up in butcheries now [that] they realize they are going to be defeated." 131 Given that the outlines of the Final Solution had been verified by credible evidence received in the United States as early as the autumn of 1942 , other factors were likely at work as well. ${ }^{132}$

Forces shaping American attitudes toward information about mass atrocities during World War II included lingering skepticism induced by inflated atrocity stories from the First World War, which some World War II-era commentators had come to see as having manipulated the American public to favor involvement in that earlier conflict. Furthermore, fears of an influx of refugees who might take newly available jobs and dilute the stock of "native" workers strengthened anti-immigrant sentiment in the United States. Anti-

129. Inter-Allied Info. Comm., Aide-Memoire from the United Kingdom, in PUNISHMENT FOR WAR CRIMINALS: THE INTER-AlLIED DECLARATION SIGNED AT ST. JAMES'S PALACE, LONDON, ON JANUARY 13, 1942, at 4 (1945).

130. Id. at 5-6.

131. Letter from British Prime Minister (Churchill) to President Roosevelt and the Chairman of the Soviet Council of People's Commissars (Stalin) (Oct. 12, 1943), reprinted in 1 FRUS 1943, supra note 82 , at $556-57$.

132. See David S. Wyman, The ABandonment of the JeWs: America AND the HolOCAUST, 1941-1945, 42, 72 (1984). 
semitism likely played a role in these "native stock" arguments. Yet the U.S. was also just emerging from a decade-long Depression where unemployment had skyrocketed. Even plentiful wartime jobs had failed to erase relatively recent memories of bread lines and soup kitchens. Wartime public opinion polls often showed that a majority of Americans predicted another economic depression after the war, with unemployment spiking as millions of young people were demobilized. The prospect of government programs admitting floods of destitute immigrants played into these fears of higher postwar joblessness, whatever the likely ethnic background of those immigrants. ${ }^{133}$

In addition, State Department officials such as Breckinridge Long argued that waivers of U.S. immigration quotas would be especially undesirable in the case of Jewish refugees, and that a deliberate policy of delay would better accomplish State Department objectives. ${ }^{134}$ Most unsettling of all, perhaps, was the role played by highly assimilated American-Jewish leaders such as presidential advisor Samuel I. Rosenman, who consistently sought to water down the president's public statements on war crimes, and insisted that FDR refuse meetings with groups advocating on behalf of Holocaust victims. ${ }^{135}$ The present author's admittedly charitable theory about Rosenman is that his interpretation of American pluralism meant denying the relevance of ethnicity in every context. Government officials of Jewish background were also sensitive to the accusation that they might be using their professional positions for the purpose of "special pleading" on behalf of their persecuted co-religionists. Treasury Secretary Henry Morgenthau's 1945 book for a popular audience, Germany Is Our Problem, did not refer to its author's religious background, for instance; nor-much more astonishingly, given its subject and date of publication-does it mention Jews at all. Rosenman may also have believed that large cohorts of manifestly alien-seeming co-religionist refugees would encourage the growth of American anti-semitism. ${ }^{136}$ While representatives of Jewish groups were active and persistent, they failed to influence policymakers in any executive department except the Treasury, let alone penetrate mainstream

133. See, for example, the August 1944 response to a FOR poll asking a sampling of Americans if a "widespread depression" should be anticipated within 10 years, with just over $50 \%$ responding "yes, we will have a depression" and only $35.9 \%$ indicating "we will avoid it." PUBLIC OPINION 1935-46, at 65-66 (Hadley Cantril ed., 1951). When Republicans were asked this same question in January 1945, 62.1\% predicted widespread depression between 1945 and 1955. Id.

134. WYMAN, supra note 132 , at 190.

135. Id. at 75, 256. Rosenman's lengthy political memoir does not mention Jews, the holocaust, or the fact that its author was Jewish. See SAMUEL I. RoSENMAN, WoRkING WITH ROOSEVELT (1952). This omission is particularly notable given that over half of the memoir focuses on the shaping of policy in the White House during the years 1941-45, during which time Rosenman had almost daily access to the president. Furthermore, in January and February of 1945, Rosenman headed a review team of war crimes prosecution policies, and in May and June of 1945, the former state court judge was one of the primary negotiators for the United States of the draft war crimes policy that led to the Nuremberg Charter. Id. at 518-19, 545 .

136. See, e.g., The German-JewISH LegaCY IN AMERICA, 1938-1988: From BILdUNG TO THE BILL OF RIGHTS (Abraham J. Peck ed., 1989). 
American consciousness. ${ }^{137}$

An innate human tendency simply to deny the reality of such shocking news of such mass slaughters likely played a role as well. ${ }^{138}$ Even the November 1943 Moscow Declaration referred to what would become known as the Holocaust incredibly obliquely, as "the slaughters inflicted on the people of Poland." 139 Nuremberg assistant prosecutor Telford Taylor remembered that the establishment of the War Crimes Commission in London "made astonishingly-indeed shamefully-little impact on the public mind. I myself did not become aware of the Holocaust until my exposure to the relevant documents and witnesses at Nuremberg."140

In the wake of the Moscow Declaration, officials in the War Department developed several general plans, starting with the Handbook on Military Government for Germany, which included an annex on war criminals. The Handbook included a table listing "categories of Nazi officers" to be "arrested and detained upon the Allied Occupational Forces' entry into Germany," estimated to add up to well over 100,000 potential detaineees in the Western Zone of occupation alone. ${ }^{141}$ In the summer of 1944, however, with overall denazification policy still unsettled, it was not possible to be more specific about the fate of those detained. Plans for their processing would most likely have grown out of the guiding principles of this War Department Handbook, as summarized by its admonition to occupation authorities:

Your main and immediate task, to accomplish your mission, is to get things running, to pick up the pieces, to restore as quickly as possible the official functioning of the German civil government in the area for which you are responsible .... The first concern of military government will be to see that the machine works and works efficiently. ${ }^{142}$

In large part, this War Department approach of treating defeated Germany like a nice WPA job-i.e., like a New Deal project or agency-was what had sparked Treasury Secretary Morgenthau to develop his famously controversial alternative. ${ }^{143}$ This dynamic of stimulus and response continued through the autumn and winter of 1944, as controversy over the Morgenthau Plan became a

137. See, e.g., Statement on War Criminals Submitted by the American Jewish Conference to the Secretary of State (Aug. 25, 1944), reprinted in DOCUMENTARY RECORD, supra note 30, at 1720.

138. For example, War Department official John J. McCloy and Supreme Court Justice Felix Frankfurter discounted first-hand evidence of Holocaust-related atrocities as late as early 1944. See the nuanced account of their skepticism in DAVID M. KENNEDY, FREEDOM FROM FEAR: THE AMERICAN PEOPLE IN DEPRESSION AND WAR, 1929-1945, at 796-97 (1999). Frankfurter professed himself "unable to believe" the testimonials, more out of what he readily conceded at the time was a failure of imagination than any doubts as to the witnesses' veracity.

139. Moscow Declaration, supra note 125 , at 4.

140. TAYLOR, supra note 7 , at 26.

141. War Department Handbook, supra note 50, at 1394-96. Table D, Nazi Police, Party, Para-Military, and Governmental Officers to be Interned.

142. Id. at 1394.

143. 1 MORGENTHAU DiaRY, supra note 50, at 414 (statement of Henry A. Morgenthau, Jr., Aug. 17, 1944). 
major impetus for the War Department to develop its own plans regarding Germany's suspected war criminals.

V.

"HOWEVER MUCH A MAN LOVED THE LAW HE COULD NOT LOVE SO MUCH OF IT AS WOUND ITS SLUGGISH WAY THROUGH THE PALACE OF JUSTICE AT NUREMBERG"144

Lieutenant Colonel Murray C. Bernays was the thoughtful and bookish chief of the Special Projects Office in the Personnel Branch of the War Department. Bernays developed a plan for prosecution of war criminals that turned on charging the leaders of the Nazi regime with "conspiracy to commit murder, terrorism, and the destruction of peaceful populations in violation of the laws of war." 145 Traditionally an Anglo-American legal doctrine, the conspiracy approach would also criminalize "everything done in furtherance of the conspiracy ... [including] domestic atrocities induced or procured by the German Government to be committed by other Axis nations against their respective nationals." 146 Groups as well as individuals could be conspirators, and Bernays envisioned an initial trial of the top echelon of Nazi leaders along with representatives of groups such as the Gestapo and German General Staff.

Once the group had been declared criminal, it would merely be a matter of showing whether any given individual was a member of that group, thus purging large numbers of Nazis using judicial processes rather than summary execution. Other War Department attorneys, notably Colonel Ammi Cutter, refined the "Bernays Plan" before Secretary of War Henry Stimson enthusiastically endorsed it in late October of 1944. The criminal conspiracy approach was especially appealing, Stimson later told associates, because he himself had litigated some trust-busting conspiracy cases as a young lawyer, against sugar combines, and had found the doctrine to be both rigorous and efficient. ${ }^{147}$

American planning for Axis war crimes trials bogged down in the winter of 1944-45 in the face of inter-departmental opposition, mostly from the offices of the Judge Advocate General and, later, the State Department Legal Advisor. Officials in these offices, as well as Herbert Weschler in the Justice Department (later a supporter and advisor at Nuremberg), objected to the concept of including pre-war atrocities against a domestic population, since the strictures of the laws of war were presumably triggered only by an underlying international armed conflict. They also expressed concerns about guilt-by-association problems presented by the conspiracy scheme. But in late January 1945, an unexpected infusion of popular fervor dramatically cut through these

144. WEST, supra note 22, at 17.

145. Trial of European War Criminals, supra note 30.

146. Id. at $36-37$.

147. Henry L. Stimson \& McGeorge Bundy, On Active Service IN PEace AND War 586-87 (1947). 
bureaucratic debates, galvanizing plans for an ambitious and high-profile trial of Nazi leaders.

On December 17, 1944, during the Battle of the Bulge, the First SS Panzer regiment had machine-gunned seventy American prisoners at Malmédy, Belgium. This event convinced Attorney General Biddle that the Nazis were indeed perpetrating a criminal conspiracy to violate the laws of war. ${ }^{148}$ "Malmédy fever" started slowly in late December, but continued heating up through January and February. ${ }^{149}$ The Malmédy fever syndrome is a stark vindication of political scientist Gary Bass's famous thesis that countries are only galvanized to pursue the remedy of war crimes trials when enemy atrocities are directed against their own nationals. While the slaughter of these seventy American prisoners in late 1944 was doubtlessly very shocking to American sensibilities, it is equally amazing, in its own way, that the slaughter of millions of non-combatant European Jews of all ages and both genders over the preceding three years had failed to generate even a small percentage of the same kind of outrage. The Bass thesis is at root a commentary on the limits of empathy and the links between empathy, mobilization, and policy. "Malmédy fever" gave the proponents of the modified Bernays Plan the advantage they needed to push through their model of the trial of Axis leaders and organizations. It also gave administration officials charged with negotiating war crimes policy enough confidence to push their plans through over British objections that the proposed trials would be too innovative and complicated. American attitudes toward Axis atrocities thus shaped how such atrocities came to be defined and prosecuted at Nuremberg. 150

Recalled from his diplomatic mission in London to impose an Americanstyle war crimes policy by the unexpected death of President Roosevelt, Sam Rosenman continued refining blueprints for what became the Nuremberg Charter in a series of informal negotiations at the UN San Francisco Conference. $\mathrm{He}$ was joined in some of these discussions by the recently appointed "Chief Prosecutor for Axis Criminality," Supreme Court Justice Robert H. Jackson. A consummate New Dealer since his days as a small-time practitioner in upstate New York, a junior colleague observed that "Robert $H$. Jackson was not one of the legal Brahmins typical of the Stimson group."151 Jackson had not attended college, and after a year at Albany Law School, he "read articles" in a law office before sitting for the New York Bar. Telford Taylor noted that Jackson was "probably the last nationally prominent lawyer to gain admission to the bar by serving an apprenticeship rather than by a law school degree"-a common

148. See Francis Biddle, Memorandum re Punishment of Criminals (Jan. 5, 1945), reprinted in DOCUMENTARY RECORD, supra note 30, at 91-92. Biddle also notes, "I think we should eliminate, at this point at least, any attempt to punish crimes committed before the war. We will have our hands full with crimes after the [declaration of] war." Id. (emphasis in original).

149. Id. at 52 .

150. See the narrative in BASS, supra note 38 , at 177-90.

151. TAYLOR, supra note 7 , at 43 . 
nineteenth-century practice for impecunious aspiring attorneys. ${ }^{152}$

In the $1930 \mathrm{~s}$, this self-made professional had attracted the attention of leading New York State politicians, including Franklin Roosevelt, Herbert Lehman, and Henry Morgenthau, Jr. Robert Jackson was soon serving ably in a series of increasingly prestigious legal posts in the first three Roosevelt administrations, first as General Counsel of the Bureau of Internal Revenue in 1934, then as Assistant Attorney General in 1936, Solicitor General in 1938, and Attorney General in January 1940, before being nominated as Associate Justice of the Supreme Court in July 1941.

Jackson had been a supporter of the idea of individual responsibility for war crimes since the so-called Saboteur's Case had come before the Supreme Court in 1942, piquing his interest in the laws of war. ${ }^{153} \mathrm{He}$ had also made several speeches expressing his belief that the 1928 Kellogg-Briand Pact had outlawed international aggression. 154 "Thus, when Samuel Rosenman entered Justice Jackson's office on April 26, 1945, to convey President Truman's wish to appoint Jackson as his country's Representative and Chief Counsel for war crimes, he was talking to a man who already had a considerable public record on the subject and who would be a strong advocate of a charge based on the illegality of aggressive war," explained Taylor. ${ }^{155}$

An excerpt from one of these after-dinner speeches offers a window into Jackson's vision of a growing and changing role for multilateral organizations generally, which would later parallel his vision of a dynamic "common law" theory of public international law at Nuremberg. Of the inadequacy of the interwar League of Nations system, Jackson observed:

We now see that such an instrumentality, if it is to compose the world's discord, must have flexibility. Neither maps nor economic advantages nor political systems can be frozen in a treaty. Peace is more than the fossilized remains of an international conclave. It cannot be static in a moving world. Peace must function as a going concern, as a way of life with a dynamic of its own.

In these comments, Jackson espoused a common anti-imperialist orientation which he shared with many other New Dealers, such as Harold Ickes. Jackson continued his history lesson:

Unfortunately, however, the internal structure of the League loaded the dice in favor of the perpetuation of the status quo which was also the policy of the dominant powers and the governing classes within them. Any peace that is indissolubly wedded to a status quo-any status quo-is doomed from the beginning. The world will not forego movement and progress and readjustments

152. Id.

153. See ex parte Quirin, 317 U.S. 1 (1942). Chief Justice Stone wrote for the Court that "[f]rom the very beginning of its history this Court has recognized and applied the law of war as including that part of the law of nations which prescribes for the conduct of war, the status, rights, and duties of enemy nations as well as of enemy individuals." $I d$. at 27-28.

154. See, e.g., Robert H. Jackson, The Challenge of International Lawlessness, Address Before the American Bar Association, Indianapolis (Oct. 2, 1941), in 27 A.B.A. J. 690 (1941).

155. TAYLOR, supra note 7 , at 45 .

156. Jackson, supra note 154, at 692. 
as the price of peace. ${ }^{157}$

This November 1941 speech also mentioned the international security provision of the Atlantic Charter-that one of the Atlantic Charter peace aims was to be the "establishment of a wider and permanent system of general security"--while warning that:

such happy days wait upon great improvement in our international law and in our organs of international legislation and adjudication. Only by well considered steps toward closer international cooperation and more certain justice can the sacrifices which we are resolved to make be justified. 158

\section{VI. \\ Negotiating the NuRemberg Charter}

There were three main "legal" controversies growing out of the plan for trying the Nazi leaders, soon to be known as the Nuremberg Charter, which was finalized at a conference in the summer of 1945 among legal delegations from Britain, France, the Soviet Union, and the United States. ${ }^{159}$ Jackson was the head of the American group, and Taylor argued that his bombastic style and inability to manage a team made each of these differences of perspective even more contentious. ${ }^{160}$ Bradley Smith noted delicately that "[a]mateur negotiating teams, such as Jackson's, tended to embody . . . national characteristics undilutedly; and with little experience in diplomacy, they plunged forward recklessly."161

The first question was whether aggressive war was already illegal under a traditional, positivist approach to legal analysis. The jurists agreed that the 1928 Kellogg-Briand Pact had outlawed aggressive war, even though that treaty did not provide specific sanctions for violations of its provisions. Critics of the Nuremberg approach often noted that this argument was significantly weakened by the inability of the Charter's drafters to agree on a definition of aggression. The drafters rejected the idea that they were charging the defendants under a retroactive, ex post facto charge, since as Jackson had explained in an earlier memorandum, they were charging the defendants with crimes that had been

157. Id.

158. Id. at 693 (internal quotation omitted)

159. The London Conference began on June 26, 1945, the day the United Nations Charter was signed in San Francisco, and ended August 7, 1945, the day news reports were published describing the previous day's explosion of an American atomic weapon over Hiroshima. The memoranda and summaries of negotiation sessions of the London Conference are reprinted in REPORT OF ROBERT H. JACKSON, supra note 91. The other most active negotiators were Professor André Gros of France; Sir William Jowitt and Sir David Maxwell-Fyfe of Britain; and Ion T. Nikitchenko and General Roman A. Rudenko of the Soviet Union. Note that three of the major negotiators of the Nuremberg Charter, Jackson, Maxwell-Fyfe, and Rudenko, were soon to become prosecutors, while another, Nikitchenko, would soon become one of the judges.

160. On Jackson's management skills and negotiation style, see generally TAYLOR, supra note 7 , at 116-64.

161. BRAdLEy F. SMITH, REACHING JUdGMENT AT NUREMBERG 47 (1977). 
recognized since the time that Cain slew Abel. ${ }^{162}$ The judgment noted that the prohibition on ex post facto legislation had its origin in principles of equity, and it did not seem reasonable to the Allies that the Axis leaders could not have known they were doing wrong before they were actually indicted. ${ }^{163}$ Still, at the London Conference, the cautious and legalistic British and French delegates were troubled by the unusually blunt language in the American draft of the Charter about the pre-existing illegal status of aggressive war. ${ }^{164}$

The second major controversy at London, which continued through the trial, was the scope of application of the conspiracy charge. Was the legal doctrine of conspiracy really going to serve as the new broom that would sweep up thousands of Gestapo members, as Murray Bernays and his boss, Henry Stimson, had hoped in the autumn of 1944? At the Charter negotiations, this controversy was also a cross-cultural issue, since conspiracy was a purely Anglo-American legal doctrine. The French were particularly unenthusiastic and periodically revived their argument that the Charter should not embrace this theory. The British also considered its application against groups to be particularly suspect. ${ }^{165}$ The Nuremberg court later expressed its continuing discomfort with the concept by making sure that no defendant was convicted for the crime of conspiracy alone. It also threw out the charge against particular organizations it considered to be lacking the requisite cohesion and decisionmaking integrity to function as a criminal organization, or whose membership had thoroughly changed over time, such as the German General Staff. ${ }^{166}$

The third major legal issue the Charter needed to address was the rationale and legitimacy of treating "murder, extermination, enslavement, deportation, and other inhumane acts committed against any civilian populations" as an indictable category of criminal activities known as "crimes against humanity." The genesis of this term is somewhat obscure. Most commentators depict the idea as originating with Nuremberg itself, but this is clearly not the case. In his 1904 State of the Union Message, President Theodore Roosevelt had explained that:

there are occasional crimes committed on so vast a scale and of such peculiar horror as to make us doubt whether it is not our manifest duty to endeavour at least to show our disapproval of the deed and our sympathy with those who have suffered by it .... [I]n extreme cases action may be justifiable and proper." 67

Roosevelt was using this rationale to justify American intervention in

162. See Atrocities and War Crimes, Report of Robert H. Jackson to the President (June 7, 1945), reprinted in 12 DEP'T ST. BULL. 1075 (1945).

163. 1 IMT NUREMBERG, supra note 2, at 219.

164. See Revision of American Draft of Proposed Agreement (June 14, 1945), reprinted in REPORT OF ROBERT H. JACKSON, supra note 91, at 58.

165. Minutes of Conference Session (July 2, 1945), reprinted in REPORT OF ROBERT H. JACKSON, supra note 91, at 129-42; see also Ferdinand A. Hermes, Collective Guilt, 23 NOTRE DAME LAW 431 (1948).

166. I IMT NUREMBERG, supra note 2, at 255-78.

167. Theodore Roosevelt, State of the Union Message (1904), reprinted in THE HUMAN RIGHTS READER 147 (Walter Laqueur \& Barry Rubin eds., 1979). 
Panama and Cuba. Interestingly, he also mentioned "intolerable conditions" suffered by Armenians and Jews in his catalogue of "systematic and longextended cruelty and oppression." 168

Theodore Roosevelt was one of the initiators of the 1907 Hague Conference, convened to revise and extend the Hague Conventions of 1899. The Hague Conventions on the Laws and Customs of War on Land of both 1899 and 1907 had the following clause in their preambles:

Until a more complete code of the laws of war has been issued, the high contracting Parties deem it expedient to declare that, in cases not included in the Regulations adopted by them, the inhabitants and the belligerents remain under the protection and rule of the principles of the laws of nations, as they result from the usages established among civilized peoples, from the laws of humanity, and the dictates of the public conscience.

This was the famous Martens Clause, named after its drafter and advocate, the Russian legal scholar Feodor Martens, and designed to cover both the kind of unconscionable but non-traditional situation Roosevelt described in his 1904 speech, as well as the development of weaponry with new and unanticipated capacities. 170

Another provision of this same treaty, however, contained a clause that seemed radically to restrict the expansive implications of the Martens clause. This was the so-called si omnes clause, specifying that " $[t]$ he provisions [of this Convention] do not apply except between contracting Powers, and then only if all belligerents are parties to the Convention."171 In other words, if two nations are at war and only one is a signatory to the Hague Conventions, then that treaties' provisions would not apply to either party, and if several warring countries are at war at once, the Convention would not apply to any of them unless all were signatories.

The competing legal theories of prosecution and defense at Nuremberg can be seen as a struggle between the expansive, organic "Martens" approach to legal interpretation-extending protections drawn from the "principles of the laws of nations, ... the usages established among civilized peoples, . . . the laws of humanity, and the dictates of the public conscience" to situations where no formal law yet applied-and the narrow, positivist si omnes approach. German defense counsel made good use of the si omnes clause at Nuremberg, arguing that several of the combatant nations in World War II had not signed the Hague Conventions, for example, and so none of the combatants, including Germany, could appropriately be bound by the Hague rules.

In its judgment, the Nuremberg court "brushed aside this contention."172 The tribunal determined that, "by 1939 these rules laid down in the [Hague]

168. Id. at $147-48$.

169. Fourth Hague Convention, supra note 38, Preamble, 36 Stat. at 2280,1 Bevans at 633.

170. See The Hague Conventions AND DeClarations OF 1899 AND 1907, at 100-27 (James Brown Scott ed., 3d ed. 1918).

171. Fourth Hague Convention, supra note 38, art. 2, 36 Stat. at 2296, 1 Bevans at 644 .

172. TAYLOR, supra note 7 , at 582 . 
Convention were recognized by all civilized nations, and were regarded as being declaratory of the laws and customs of wars which are referred to in Article 6(b) of the [Nuremberg] Charter."173 The tribunal recognized the 1907 Hague Convention as declaratory of customary international law and framed its judgment on innovative charges, such as crimes against humanity, on the flexible basis of the Martens clause. ${ }^{174}$

The leading French negotiator at the August 1945 London Conference, Robert Falco, had doubted the existence of a separate category of "crimes against humanity," preferring to construe German atrocities as an extreme example of the more traditional concept of conventional war crimes. But by the time the French prosecutor, François de Menthon, came to present his case, the French team had undergone a philosophical shift. Crimes against humanity, de Menthon now argued, were "crimes against the spirit," and the source from which all the other crimes in the Charter flowed:

I propose . . . to prove to you that all this organized and vast criminality springs from what I may be allowed to call a crime against the spirit, I mean a doctrine which, denying all spiritual, rational, or moral values by which the nations have tried, for thousands of years to improve human conditions .... This monstrous doctrine is that of racialism.

De Menthon then linked institutionalized racism to violations of individual human dignity. "Race is the matrix of the German people; proceeding therefrom this people lives and develops as an organism .... National Socialism ends in the absorption of the personality of the citizen into that of the state and in the denial of any intrinsic value of the human person."176

Jackson based the crimes against humanity charge on Martens clause precepts by means of an analogy with the growth of Anglo-American common law. His peroration in his Opening Statement harked back to his 1941 speech to the Bar Association of Indianapolis, with its image of law as an evolving, organic entity:

The real complaining party at your bar is Civilization. In all our countries it is still a struggling and imperfect thing. It does not plead that the United States or any other country has been blameless .... Civilization asks whether law is so laggard as to be utterly helpless to deal with crimes of this magnitude by criminals of this order of importance. It does not expect that you [the Tribunal] can make war impossible. It does expect that your juridical action will put the forms of international law, its precepts, its prohibitions, and most of all, its sanctions, on the side of peace.

The Tribunal agreed, explaining in its judgment that:

173. 1 IMT NUREMBERG, supra note 2, at 254 .

174. Revised Draft of Agreement and Memorandum Submitted by American Delegation (June 30, 1945), in REPORT OF ROBERT H. JACKSON, supra note 91, at 121 (American Memorandum at the London Conference mentioning the Martens clause).

175. 5 IMT NUREMBERG, supra note 2, at 373.

176. Id. at 373-74.

177. Int'L Military tribunal, the trial of german Major War Criminals: OPENING SPEECHES OF THE CHIEF PROSECUTORS 34 (1946) [hereinafter OPENING SPEECHES]. 
The law of war is to be found not only in treaties, but in the customs and practice of states which gradually obtained universal recognition, and from the general principles of justice applied by jurists and practised by military courts. This law is not static, but by continual adaptation follows the needs of a changing
world.

Another contentious aspect of the idea of crimes against humanity was the scope of its application: would this charge apply to pre-war atrocities inflicted on Germany's own domestic population? The text of the Judgment reflected the Nuremberg court's decision not to address pre-war atrocities against domestic minorities despite some ambiguous language in the Charter. ${ }^{179}$

The prosecution at Nuremberg argued that, under the terms of the Charter, the count of crimes against humanity should indeed encompass German atrocities committed within Germany and against German nationals. Even before the German invasion of Poland in 1939 transformed the status of this state-sponsored violence into an international armed conflict, crimes against humanity, wherever committed, ought to be considered a violation of international law. What the prosecution argued, in effect, was for the conspiracy charge in 6(a) to be applied to all three sections of the Charter-an especially plausible contention given the last sentence of Article 6. The pre-war atrocities would be considered an early part of the "conspiracy" phase of waging aggressive war or committing crimes against humanity.

But the British prosecution team had overreached in arguing that this

178. 1 IMT NUREMBERG, supra note 2, at 221.

179. Article 6 of the Nuremberg Charter provided that:

The Tribunal established by the Agreement referred to in Article 1 hereof for the trial and punishment of the major war criminals of the European Axis countries shall have the power to try and punish persons who, acting in the interests of the European Axis countries, whether as individuals or as members of organizations, committed any of the following crimes.

The following acts, or any of them, are crimes coming within the jurisdiction of the Tribunal for which there shall be individual responsibility:

A. CRIMES AGAINST PEACE: namely, planning, preparation, initiation or waging of a war of aggression, or a war in violation of international treaties, agreements or assurances, or participation in a common plan or conspiracy for the accomplishment of any of the foregoing;

B. WAR CRIMES: namely, violations of the laws or customs of war. Such violations shall include, but not be limited to, murder, ill-treatment or deportation to slave labour or for any other purpose of civilian population of or in occupied territory, murder or illtreatment of prisoners of war or persons on the seas, killing of hostages, plunder of public or private property, wanton destruction of cities, towns, or villages, or devastation not justified by military necessity;

C. CRIMES AGAINST HUMANITY: namely, murder, extermination, enslavement, deportation, or other inhumane acts committed against any civilian population, before or during the war; or persecutions on political, racial, or religious grounds in execution of or in connection with any crime within the jurisdiction of the Tribunal, whether or not in violation of the domestic law of the country where perpetrated.

Leaders, organizers, instigators, and accomplices participating in the formulation or execution of a common plan or conspiracy to commit any of the foregoing crimes are responsible for all acts performed by any persons in execution of such plan.

Nuremberg Charter, supra note 6, art. 6, 59 Stat. at 1547, 82 U.N.T.S. at 286-88. 
conspiracy stretched back to the creation of the Nazi Party in 1919. The French judge, Donnedieu de Vabres, had never been comfortable with the conspiracy charge to begin with, and he balked at the prospect of an international court applying this strange Anglo-American concept to twenty additional years of German national life.

The tribunal's decision on pre-war atrocities was a compromise awkward even by legal standards, based on a very strict reading of Article 6 . The judgment held that the atrocities mentioned in section 6(c) were only meant to include acts that were carried out "in connection with, any crime within the jurisdiction of the Tribunal," meaning the provisions described in sections 6(a) and 6(b), for which the specified starting date was September 1, 1939. ${ }^{180}$ Before the invasion of Poland, in other words, it "ha[d] not been satisfactorily prove[n] that [these atrocities] were done in execution of, or in connection with, [the crimes against peace specified in section 6(a).]"181 The tribunal therefore declared itself as having no jurisdiction over these "domestic" German atrocities: "The Tribunal cannot make a general declaration that the acts before 1939 were Crimes Against Humanity within the meaning of the Charter."182

The Nuremberg judges were apparently troubled by some of the same domestic jurisdiction issues that had alarmed American critics of the original Bernays "conspiracy" approach. This cautious view was best articulated by Jackson himself at the London Conference, when he was speaking as a representative of the Roosevelt administration and not yet serving as an active prosecutor:

It has been the general principle of foreign policy of our Government from time immemorial that the internal affairs of another government are not ordinarily our business; that is to say, the way Germany treats its inhabitants, or any other country treats its inhabitants, is not our affair any more than it is the affair of some other government to interpose itself in our problems.

Here, Jackson articulated the standard U.S. interpretation, reaffirmed during the World War I and interwar era. ${ }^{183}$ "The reason that this program of extermination of Jews and destruction of the rights of minorities becomes an international concern is this: it was a part of a plan for making an illegal war." 184

Jackson thus foreshadowed the Nuremberg judgment's approach to Article 6 , of requiring a tight nexus between crimes against humanity and the aggressive war charge-a nexus not necessarily indicated by the plain language of the Article itself. Jackson also went on to offer this unusually candid elucidation:

[O]rdinarily we do not consider that the acts of a government toward its own citizens warrant our interference. We have some regrettable circumstances at

180. 1 IMT NUREMBERG, supra note 2, at 254.

181. Id.

182. Id.; see also TAYLOR, supra note 7, at 583.

183. Minutes of Conference Session (July 23, 1945), reprinted in REPORT OF ROBERT H. JACKSON, supra note 91 , at 331 .

184. Id. 
times in our own country in which minorities are unfairly treated. We think it is justifiable that we interfere or attempt to bring retribution to individuals or to states only because the concentration camps and the deportations were in pursuance of a common plan or enterprise of making an unjust or illegal war in which we became involved. We see no other basis on which we are justified in reaching the atrocities which were committed inside Germany, under German law, or even in violation of German law, by authorities of the German state.

Prewar atrocities could not be "reached" by the Tribunal because of fears over the implications of international bodies sitting in judgment on domestic practices, even when those practices were clearly crimes against humanity by any reasonable criteria. There was no principle available that could capture Kristallnacht in Germany but spare the lynching of thousands of AfricanAmericans in the American South.

In a 1946 letter to the New York Times, Raphael Lemkin, a former Nuremberg prosecution advisor who had coined the term "genocide," wrote wonderingly of this "lack of reach" argument: "It seems inconsistent with our concepts of civilization that selling a drug to an individual is a matter of worldly concern,"- the regulation of transborder flows of narcotics had long been subjected to international oversight through treaties and multilateral institutions-"while gassing millions of human beings might [merely] be a problem of internal concern." 186

VII.

\section{OTHER TRIAL ISSUES}

The prosecution staff thought it essential that the Tribunal base its judgment on the Nuremberg Charter. The Charter was a treaty in its own right, they argued, legitimately filling the legal vacuum created by Germany's unconditional surrender. The Tribunal agreed and denied all defense motions challenging its jurisdiction. ${ }^{187}$ Other types of controversies based on the Nuremberg approach included criticisms of the overall design of the trial; the Charter's treatment of conflicting, pre-existing legal ideas such as the "act of state" doctrine; criticism of the trial as an American or Jewish show trial; and how the Nuremberg model came to be generalized and applied to other trials in the wake of World War II.

The major criticism of the overall design of the main Nuremberg trial related to the uncomfortable presence of uniformed Soviet officers on the bench, judging Axis defendants for the crime of aggression, when the Soviets had themselves invaded Poland in 1935 and Finland a year later. Furthermore, one of the counts of the Indictment charged the German defendants with the massacre of thousands of Polish officers in the Katyn Forest, an atrocity widely

185. Id. at 333 .

186. Raphael Lemkin, Letter to the Editor, Genocide Before the U.N., N.Y. TIMES, Nov. 8, 1946 , at 22 .

187. 1 IMT NUREMBERG, supra note 2, at 218-19. 
suspected at the time (and subsequently confirmed) to have been committed by Soviet forces. Similar criticisms were leveled against the other Allies for using the same type of unrestricted submarine warfare for which the defendants had been indicted; for the Allied use of terror bombing against civilians; and, especially, for the American use of atomic weapons against civilian targets. Posed starkly, these concerns amounted to an accusation of hypocrisy-of "unclean hands," or what in international legal parlance is known as $t u$ quoque-"you did it, too." Another facet of this charge of hypocrisy was the only slightly less virulent criticism that the trial lacked legitimacy because only victor nations were represented on the bench.

The tu quoque objection to the Nuremberg proceedings was stated most clearly by the perennial U.S. presidential candidate, socialist Norman Thomas, writing in 1947. "Our socialist proposals never precluded the trial and punishment of those guilty of atrocities against civilians and prisoners of war"that is to say, for conventional war crimes--"[f]or that [crime] there was sufficient law already recognized." 188 But, Thomas continued, such principles:

did preclude trials of the sort that are dragging along in Nuremberg and Tokyo as this is being written. Aggressive war is a moral crime but this will not be established in the conscience of mankind by proceedings such as those at Nuremberg, where Russians sit on the bench and exclude evidence of Hitler's deal with Stalin. What was the latter's war against Finland, Poland and the Baltic states but aggression? ${ }^{189}$

He continued:

Indeed, what major power had not in comparatively recent years been guilty of acts of aggression? Mr. Justice Jackson makes much of the analogy of the growth of common law to justify the Nuremberg proceedings. The very composition of the court by victors who are at once judges and prosecutors refutes his analogy. 190

It did not help when U.S. Admiral Chester Nimitz provided a deposition to the German defense team in support of Admiral Karl Doenitz, attesting that the Germans' conduct of submarine warfare was the same as the Americans'.191 The prosecution's unsatisfactory response was that simply because some robbers went unpunished did not mean that stealing wasn't a crime. More to the point was Jackson's poetic vow about the future legitimacy of such charges, which would go on to become the trial's most hollow legacy: "We must never forget that the record on which we judge these defendants to-day is the record on which history will judge us to-morrow. To pass these defendants a poisoned chalice is to put it to our own lips as well."192

188. NORMAN THOMAS, APPEAL TO THE NATIONS 68 (1947).

189. Id. at $68-69$.

190. Id. at 69

191. Doenitz was acquitted. See CONOT, supra note 11, at 68; see also WILliAM J. BosCH, JUDGMENT ON NUREMBERG: AMERICAN ATTITUDES TOWARD THE MAJOR GERMAN WAR-CRIME Trials, 168-69 (1970); Howard BALl, Prosecuting War Crimes and Genocide: The TWENTIETH-CENTURY EXPERIENCE 58 (1999).

192. OPENING SPEECHES, supra note 177, at 5. 
The traditional legal idea of sovereign immunity, also known as the "act of state" doctrine, protected heads of governments and other high officials from individual liability for their political decisions. Lower level officials, especially soldiers and other military subordinates, relied on a complementary traditional legal idea, that they were insulated from personal culpability by a doctrine of "superior orders." 193 The combination of the two doctrines negated the responsibility of all actors high and low, and meant that no one was responsible.

Unsurprisingly, given the deaths of the top echelon of Reich officials, defenses claiming incontrovertible superior orders were extremely popular at Nuremberg. This was true even though, for any given defendant, asserting the defense of superior orders inevitably involved listening to a defense attorney downplay one's personal influence, authority, access to Hitler, and overall competence. Psychologist Gilbert noted in his diary that "[ $t]$ he innocence of the 'white lambs' was beginning to become a sort of joke" in the defendants' lunchroom. ${ }^{194}$ He noted wearily:

It was apparent that nobody had anything to do with anything. The Foreign Minister was only an office boy; the Chief of Staff of the High Command of the Wehrmacht was only an office manager; the rabid anti-Semites were all in favor of chivalrous solutions to the Jewish problem and knew nothing about the atrocities, including Gestapo Chief Kaltenbrunner. ${ }^{195}$

The Nuremberg Charter explicitly discarded the "act of state doctrine" as part of its mission to bring the idea of individual responsibility into the purview of international law. ${ }^{196}$ But the discounting of sovereign immunity made American and other Allied military officers nervous; they were unenthusiastic about the possible precedent that the Nuremberg prosecution staff was laying down, which would presumably restrict the scope of future claims of "superior orders." Isolationist Senator Burton K. Wheeler, as well as Admiral William Leahy, chief of staff under Roosevelt and Truman, raised concerns that congressional representative George A. Dondero of Michigan expressed succinctly. Citing a section of the Nuremberg judgment, to the effect that a subordinate was bound to obey only the lawful orders of a superior, Dondero urged his listeners to "[f]ollow the implications of this statement through to a logical conclusion. In effect, it encourages mass disobedience of superior officers within our armed forces." 197

The trial's defenders were particularly impatient with these arguments. Political scientist Nicholas Doman wrote:

193. Guenter Lewy, Superior Orders, Nuclear Warfare, and the Dictates of Conscience: The Dilemma of Military Obedience in the Atomic Age, 55 AM. POL. SCI. REV. 3, 19 (1961).

194. NUREMBERG DIARY, supra note 12, at 409 (entry for July 12, 1946).

195. Id.

196. Nuremberg Charter, supra note 6, art. 7, 59 Stat. at 1548, 82 U.N.T.S. at 288; see also John Foster Dulles, International Law and Individuals: A Comment on Enforcing Peace, 35 A.B.A. J. 912 (1949); Ernst Schneeberger, The Responsibility of the Individual Under International Law, 35 GEO. L.J. 481, 489 (1947); Lawrence Lauer, The International War Criminal Trials and the Common Law of War, 20 ST. JOHN's L. REV. 18, 24 (1945).

197. 94 CONG. REC. A-2369 (1948). 
No responsible military leader of any nation can contend that his role is merely that of a concierge or custodian of the war machine under his command and that he bears no responsibility for the use to which that machine is put.... [The defendants] are on trial not because they lost the war but because they started it. And if recognition is given to the claim of the prosecutors, then this will mean that the collective security of world society attained supremacy over the personal security of the militarists. 198

Military commentators remained skeptical, however, explaining that civilian lawyers could never understand the dynamics of battlefield decisions. Lieutenant Colonel P.F. Gault argued that, " $[\mathrm{t}]$ he basic difficulty with the whole procedure is that Nuremberg is entirely a civilian show and strictly amateur at that." 199

Nuremberg was not only a civilian show, it was also a show produced and directed almost entirely by Americans. One American journalist proudly explained:

From the very beginning of this joint effort, the United States carried the ball. Although the cooperation of other nations was genuine and sincere, there is ample proof to show that Nuremberg was a 100 per cent American concern. It was American initiative, American persistence, and American idealism that produced the final result in the face of serious difficulties .... [S]tarting from a shoestring, American enterprise has produced a powerful machine, well equipped to hand down the historic verdict and to open a new age in international good conduct. 200

The Nuremberg show was also a Robert H. Jackson production. It was Jackson who told Francis Biddle that he, Biddle, should stand aside in the election of chief judge of the tribunal, in favor of the British judge, Sir Geoffrey Lawrence, so that the trial would not be perceived as being so totally dominated by the United States. 201

Jackson also fretted about the appearance of having "too many Jews" on the prosecution staff, as a public relations problem that the American jurist believed would further reduce the trial's legitimacy, in the eyes of both German and American public opinion. Jackson's efforts on this score were of little avail. Many of the defendants as well as large numbers of ordinary Germans believed that Jews were running the trial, anyway. Defendant Streicher, the Nazi propagandist, explained to psychologist Gilbert that, "[ $t]$ he prosecution is made up almost entirely of Jews." 202 When asked how he knew this, Streicher replied that there were distinctive Jewish physical characteristics, "although there were many exceptions, and it took a real expert like himself to detect them."203

198. Nicholas Doman, Political Consequences of the Nuremberg Trial, 246 ANNALS OF AM. ACAD. OF POL. \& SOC. SCI.. 81, 88 (1946).

199. P.F. Gault, Letter to the Editor, The Nuremberg Trials, ARMY \& NAVY J., Dec. 15, 1945 , at 522.

200. Ernest O. Hauser, The Backstage Battle at Nuremberg, 218 SATURDAY EVENING POST $18,138(1946)$

201. TAYLOR, supra note 7 , at 123-24

202. NUREMBERG DIARY, supra note 12, at 411 (entry for July 13, 1946) (internal quotation omitted).

203. Id. at $410-11$. 
When pressed, he mentioned that "one could frequently tell by the eyes," and that "[m]ore significant than Jewish eyes, however, was the Jewish behind, he had discovered.",204

Isolationist elements in Congress also suggested that Nuremberg was about Jewish vengeance. Representative John E. Rankin, Democrat of Mississippi, speaking of the so-called "secondary" Nuremberg trials, drew an unfortunate parallel between the defeated Nazis and the American South, when he urged the United States to:

put a stop to the racial persecution of the people of Germany who are now helpless at out feet.... If we people of the Southern States had been treated in the same manner after the War Between the States as those people have been treated under the pressure of a certain racial minority, you would not have heard the last of it until doomsday. 205

He urged that the United States should "treat the people of Germany ... with humanity and decency, and not permit racial minorities to vent their sadistic vengeance upon them and charge it up to the United States."206

VIII.

\section{ADDITIONAL TRIALS}

The other flagship international criminal trial staged in the name of the Allies was the International Military Tribunal for the Far East, commonly known as the Tokyo Trial. ${ }^{207}$ Meant to serve as Nuremberg's Far Eastern counterpart, and based on an almost identical charter, the Tokyo Tribunal sat from June 1946 until April 1948, reading out its verdict over the course of nine days in early November $1948 .^{208}$ The Tokyo Trial presented additional crosscultural challenges based on differing Western and Japanese legal conceptions; ideas about procedures, such as the proper role of the defense attorney; as well as more difficult translation problems. (One reason the Tokyo Trial took twice as long as Nuremberg, for example, was that it could not take advantage of IBM

204. Id. at 411. For the curious, Streicher elaborated, "you can tell by the way it wobbles when they walk." Id. (internal quotation omitted); see also id. at 41 (entry for Nov. 21, 1945). An idiosyncratic sampling of ordinary Germans polled informally at the time of the trial agreed with Streicher that the trial was dominated by Jews. See WEST, supra note 22, at 53.

205. 93 CONG. REC. 9054 (1947) (statement of John E. Rankin).

206. Id.

207. This brief account of the Tokyo Trial relies on Borgwardt, supra note 95.

208. The main difference between the Nuremberg and Tokyo charters was that the prosecution at Nuremberg was handled by an international team that shared responsibility equally, whereas the Tokyo Charter provided for a single American chief of counsel, chosen by Supreme Commander General Douglas MacArthur, who would lead an "International Prosecution Section." Other differences included that the Tokyo Charter provided for eleven judges rather than Nuremberg's four, with no alternates; and the Tokyo Charter provided for review of the sentences by MacArthur while Nuremberg made no provisions for review of the sentences. The text of the Tokyo Trial Judgment itself read that, "in all material respects the Charters of this Tribunal and the Nuremberg Tribunal are identical." See Special Proclamation: Establishment of International Military Tribunal for the Far East (Jan. 19, 1946), in THE TOKYO WAR CRIMES TRIAL, 16-18 (R. John Pritchard \& Sonia Magbanua Zaide eds., 1981) [hereinafter TRANSCRIPTS]. 
simultaneous translation technology, used to great effect at Nuremberg.)

Another important difference with Nuremberg was the number of separate and dissenting opinions at Tokyo. ${ }^{209}$ Three of the eleven judges-Rahadbinod Pal of India, Henri Bernard of France, and Bernard Röling of the Netherlandsfiled dissents or partial dissents. Pal maintained in his 701-page dissenting opinion that the distinction between just and unjust war belonged to the theory of legal philosophers, and that the rule concerning the crime against peace-that aggression was illegal-was ex post facto legislation. ${ }^{210}$ Röling, on the other hand, stated that crimes against peace were not real legal crimes, but they could nevertheless be used as political safety measures to eliminate persons who were dangerous for world peace. Bernard argued that the verdict could not be valid because the procedure was defective and that the Japanese emperor should also have been punished.

Justice Pal, in addition, offered the fascinating anti-imperialist argument that had been foreshadowed by the so-called revisionist powers at the Paris Peace Conference in 1919: indicting leaders for "crimes against peace" served only to protect an unjust international order if there were no other workable provisions for peaceful adjustment of the status quo. ${ }^{211}$ Two additional judges, including the Tribunal's chief justice, filed separate opinions. Chief Justice William Webb of Australia called for a trial of the emperor and commutation of the death sentences to life imprisonment; Delfin Jaranilla of the Philippines, himself a survivor of the Bataan Death March, argued alternatively for harsher sentences. 212

The twenty-five Tokyo defendants were known as "Class A" war criminals, meaning that part of their indictment was for crimes against peace. ${ }^{213}$ Class $A$

209. The Soviet judge at Nuremberg, General Ion Timifeevich Nikitchenko, had dissented on the limited basis that he felt that the sentences were too lenient regarding those defendants who were acquitted or given prison sentences, and that in his opinion the German General Staff and Reich Cabinet were cohesive enough groups to be appropriately deemed "criminal organizations." He concurred in the tribunal's judgment on its jurisdiction and on points of law, however.

210. PAL, supra note 124. This published version of Pal's Dissent, which includes a number of elaborations and an Appendix not included in the original version, is 701 pages. The original typescript version, reproduced in 21 TRANSCRIPTS, supra note 208 , is 1,235 pages.

211. Pal wrote:

The part of humanity which has been lucky enough to enjoy political freedom can now well afford to ... think of peace in terms of political status quo. But every part of humanity has not been equally lucky and a considerable part is still haunted by the wishful thinking about escape from political dominations. To them the present age is face with not only the menace of totalitarianism but the actual plague of imperialism.

PAL, supra note 124 , at 115 . See also the discussion in Borgwardt, supra note 95 , which remains the only scholarly analysis of Pal's dissent.

212. Separate and dissenting opinions in the judgment of the Tokyo Tribunal are reprinted in 21 TRANSCRIPTS, supra note 208. RICHARD MINEAR, VICTORS' JUSTICE: THE TOKYO WAR CRIMES TRIAL 161-62 (1971) offers a trenchant, if somewhat polemical and oversimplified, critique of the legal basis of the trial. There is as yet no full-length scholarly treatment of the Tokyo Trial, although a massive narrative in several volumes, authored by Tokyo assistant prosecutor and Stanford Japanologist Kurt Steiner, has recently been completed. KURT STEINER, THE TOKYO TRIAL (forthcoming 2005).

213. The Tokyo Indictment had named twenty-eight Japanese leaders, but during the course 
defendants were tried separately from Class B and C suspects, who were arraigned for violations of the conventional laws of war. From 1945 to 1951, approximately 5,700 Japanese were tried as "conventional" war criminals for perpetrating, allowing, or ordering atrocities. Of this number, roughly 1,000 were executed and 3,000 were imprisoned. ${ }^{214}$ Most controversially, the Japanese commanding general of the Philippines, Yamashita Tomoyuki, was convicted and hanged by a U.S. Army court in Manila. Yamashita's conviction was based on a theory of negative criminality; that is, that he "unlawfully disregarded and failed to discharge his duty as commander to control the operations of the members of his command, permitting them to commit brutal atrocities." 215 The decision was controversial in large part because Yamashita's American opponents had successfully disrupted the General's lines of communication, only to hold him accountable later for having failed to control his troops. 216

For nationals of European Axis countries, there were also 2,116 known military tribunal hearings of lower-level defendants, not including those conducted in the Soviet Union. All told, more than 5,000 Nazis were condemned by all the Allied war crimes tribunals taken together, with 806 death sentences. The United States Supreme Court held that the writ of habeas corpus did not apply for appellants from these war crimes trials. ${ }^{217}$ In addition, over twelve thousand people were tried in hearings before German national courts (Spruchkammern), with sixty-eight given life terms and 5,178 given very limited prison terms. ${ }^{218}$ While the German courts applied German national law, the new postwar penal codes had incorporated legal ideas from the Nuremberg Charter regarding individual responsibility and absence of an obligation to obey orders that were illegal under international law. ${ }^{219}$

International legal scholar Robert Woetzel has noted that:

[a]ll these tribunals show a uniformity of approach to the substantive rules of

of the proceedings, two of the defendants, Matsuoka Yosuke and Nagano Osami, had died and one, Oakawa Shumei, had been declared insane and unfit to stand trial. See Borgwardt, supra note 95, at 442.

214. See Philip R. Piccigallo, The Japanese on Trial: allied War Crimes OPERATIONS IN THE FAR EAST, 1945-1951, at 213, 263 n.10 (1979)

215. In re Yamashita, 327 U.S. 1, 13-14 (1946).

216. On appeal to the U.S. Supreme Court, Justice Murphy in dissent noted that "[n]owhere was it alleged that the petitioner personally committed any of the atrocities, or that he ordered their commission, or that he had any knowledge of the commission thereof by members of his command." Id. at 34 (Murphy, J., dissenting). "The only conclusion I can draw is that the charge made against the petitioner is clearly without precedent in international law or in the annals of recorded military history." Id. at 40 (Murphy, J., dissenting). An editorial in the Army and Navy Journal, by contrast, applauded the verdict because the scale of atrocities had been such that the commanding general had "profaned the profession of arms, threatened the very fabric of international society, and failed utterly the soldier's faith." Editorial, ARMY \& NAVY J., Feb. 9, 1946, at 744 (1946); see also A. FRANK REEL, THE CASE OF GENERAL YAMASHITA (1949).

217. See, e.g., Hirota v. MacArthur, 338 U.S. 197 (1949) (Douglas, J., concurring). (1962)

218. See Robert K. WOETZEL, THE NuREMBERG TRIALS IN INTERNATIONAL LAW 230, 245

219. Id. at 230 . 
international law involved. This was undoubtedly due to the lead given by the Charter of the International Military Tribunal at Nuremberg which can be regarded as the pre-eminent tribunal in the history of modern war crimes trials. ${ }^{220}$

This assessment, written in 1962, is double-edged: Nuremberg was "preeminent" because it was the first successful synthesis and application of a wide variety of pre-existing legal ideas and political impulses. It continued to be preeminent, however, because it was also the last such attempt, at least until a revival of multilateral criminal prosecutions in the post-Cold War era.

IX.

"PERHAPS THIS IS NEW DEAL JUSTICE ... TRANSFERRED to THE INTERNATIONAL SCENE"

The Nuremberg Charter is an example of what this study has been calling the "Zeitgeist of 1945," the multilateralist sensibility that briefly gripped the United States as World War II drew to a close. "Security, welfare, and justice are the pillars of the world order for which we fight," argued the Commission to Study the Organization of Peace, a multilateralist pressure group, in $1944 .^{221}$ These aspirations "embody the hopes and dreams of countless millions of ordinary folk who yearn for a world in which their children may grow up free from the fears (and from the costs and consequences) of recurrent wars. This is what is meant by Security-freedom from the fear of aggressive war."222 The ideological roots of the Nuremberg Charter lie in the Atlantic Charter and the virtually contemporaneous United Nations Charter. ${ }^{223}$

It was largely a matter of chance that the preliminary negotiations over the provisions of the Nuremberg Charter took place at the San Francisco Conference (April-June 1945) where the United Nations Charter was being finalized. "But the coincidence is meaningful," wrote assistant prosecutor Taylor in his memoirs, quoting Robert H. Jackson's son, William, himself a lawyer and aide at Nuremberg. ${ }^{224}$ The younger Jackson later explained that "it is perhaps not commonly apprehended that the principles of Nuremberg ... go hand in hand with the organization of the United Nations as the twin foundations of an international society ordered by law." 225

The Nuremberg tribunal asserted that its Charter was contributing to a broad historical trend affirming the universal value of international moral and legal sanctions, which had been a growing force in international affairs since at

220. Id.

221. Fourth Report of the Commission to Study the Organization of Peace, in 22 INTERNATIONAL CONCILIATION 68 (1944)

222. Id.

223. The United Nations Charter was being drafted from April-June 1945; the Nuremberg Charter, part of the London Agreement of August 8, 1945, was being drafted from June-August 1945.

224. TAYLOR, supra note 7 , at 42 (quoting William Jackson).

225. Id. 
least the end of the First World War, and which had achieved the status of positive law with the promulgation of the 1928 Kellogg-Briand Pact. President Truman expressed his hope that "we have established for all time the proposition that aggressive war is criminal and will be so treated."226 The Nuremberg Charter, and the tribunal's judgment based on that Charter, had been conceived by its authors as a means of lifting international justice to a new and higher level. Shortly after the judgment was announced, Judge Biddle wrote:

[Nuremberg's] judgment has formulated, judicially for the first time, the proposition that aggressive war is criminal and will be so treated .... [N]ow that it has been so clearly recognized and largely accepted, the time has come to make its scope and incidence more precise .... I suggest that the time has now come to set about drafting a code of international criminal law. 27

Even more lyrically, the usually more circumspect Walter Lippmann weighed in with an assessment that he had pointedly withheld from "thinner" multilateralist statements such as the Atlantic Charter:

For my own part, I do not think it rash to prophesy that the principles of this trial will come to be regarded as ranking with the Magna Charta, the habeas corpus and the Bill of Rights as landmarks in the development of law. The Nuremberg principle goes deeper into the problem of peace, and its effect may prove to be more far-reaching than anything else that has yet been agreed to by the peoples of the world. ${ }^{2}$

Attorney General Tom C. Clark echoed Lippmann in observing that " $[\mathrm{t}] \mathrm{he}$ Ten Commandments, Magna Carta and the Constitution of the United States, have been giant forward steps on the slow and dreadful path to human justice. This age has just given us the judgment at Nuremberg."229 Historian Eugene Davidson explained the sources of this hyperbolic rhetoric: "The [Nuremberg] trials were intended not only to bring the guilty to justice.... In addition, the trials, especially as the Americans saw them, were to be a projection of the new world order that would justify the universal suffering [of wartime] .... [This was what] the Allies had been fighting for." 230 Here were war and peace aims made real: Nuremberg as embodying and institutionalizing the Atlantic Charter.

Few others were quite so enthusiastic. Critics argued that the trial's controversial design, basis in law, and "streamlined" procedures so undermined the enterprise's legitimacy that the assize itself was an exercise in hypocrisy. Theologian Reinhold Niebuhr worried that the trial might plunge the defeated Germans into existential despair. ${ }^{231}$ Others noted with disfavor the likely effect

226. Harry S. Truman, Prosecution of Major Nazi War Criminals, 15 DEP'T ST, BULL. 954

227. Gordon Ireland, Ex Post Facto from Rome to Tokyo, 21 TEMPLE L. Q. 27, 54-55 (1947) (quoting Francis Biddle); see also Robert H. Jackson, Nuremberg in Retrospect: Legal Answer to International Lawlessness, 35 A.B.A. J. 813, 887 (1949). (1946).

228. Walter Lippmann, The Meaning of the Nuremberg Trial, 63 LAdIES' HomE J. 32

229. Nuremberg Hailed as Barrier to War, N.Y. TIMES, Oct. 21, 1946, at 15 (quoting Attorney General Tom C. Clark) (internal quotation omitted).

230. DAVIDSON, supra note 17, at 2 (1966).

231. Reinhold Niebuhr, A Report on Germany, in 2 CHRISTIANITY \& CRISIS 13 (1946). 
of the trial on the victors themselves:

For the plain citizen of every country, [the trial] serves to reduce the vast and infinitely complex tragedy of the Second World War to the simple abstraction of a movie melodrama, so that with the final titillating scene on the gallows or before the firing-squad, he can relax in an untroubled moral glow, confirmed in his abiding faith that 'crime never pays,' that his own country is the fount and citadel of all the virtues. 232

Legal positivists, who understood "law" as growing exclusively from the formal consent of sovereigns to be bound, also understood the Nuremberg Charter and the Tribunal's verdict as challenging traditional ideas about sovereignty. Legal scholar Quincy Wright argued that, "[Nuremberg's] principles if generally accepted may reduce the unity of the state, increase the difficulties of maintaining domestic order, and deter statesmen from pursuing vigorous foreign policies when necessary in the national interests." 233 Another widely-respected authority on international legal affairs, Manley O. Hudson of the inter-war Permanent Court of International Justice, noted pessimistically in 1943 that international judicial agencies set up to deal with war criminals probably had few prospects for developing "a continuing character," at least until some future time when "the need for international action is clearly demonstrated." 234

Journalist Ernest $O$. Hauser saw a link between Nuremberg's legal innovations and the loose "New Deal" approach to problem solving. Early in 1946, he explained:

The ambitious project of creating rather than merely applying international law, and of setting a new standard for good conduct in the family of nations, is essentially Rooseveltian. It can be traced directly to the late President, and it is fascinating to observe how the grandiose concepts as well as the vagueness characteristic of Franklin D. Roosevelt, are in evidence at Nuremberg.

Military historian Alfred A. Vagts developed a similar analogy in his later, more

232. Waldo R. Browne, Correspondence, The Nuremberg Trial, 113 NEW REPUBLIC 872 (1945); see also Reinhold Niebuhr, Victors' Justice: The War Crimes Trial, 15 COMMON SENSE 6 (1946); Paul W. Tatge, Letter to the Editor, The Nuremberg Trials: 'Victor's Justice'? 36 A.B.A. J. 247 (1950) (arguing that the United States demonstrated a "Jehovah complex" at Nuremberg).

233. Quincy Wright, The Law of the Nuremberg Trial, 41 AM. J. INT'L L. 38, 45 (1947). For additional unfavorable comments, see generally the coverage in the Chicago Tribune, such as The Nuremberg Blunder, CHIC. TRIB., Oct. 16, 1946, at 22.

234. Manley O. Hudson, Confidential Memo No. 7, in 2 INTERnational TRIBUNALS IN THE POST-WAR WORLD: A PROPOSED INTERNATIONAL CRIMINAL COURT 7 (1943). This memo was prepared as part of a series for an informal wartime working group of American and Canadian lawyers "attempting to arrive at a community of views with reference to the future of international law." By the spring of 1943 , the group was trying to reach out to include more participants with policy experience and, accordingly, included invitations to Dean Acheson, Hamilton Fish Armstrong, Adolph Berle, Isaiah Bowman, Ben Cohen, Oscar Cox, Isador Lubin, Archibald McLeish, Samuel Rosenman, Sumner Welles, and Harry Dexter White to the May 2, 1943 meeting. Draft invitation, March 1943; container 10; folder: Manley Hudson, International Courts 1942-45, Benjamin V. Cohen Papers (memos and replies were forwarded to Cohen by Hudson's assistant, Louis Sohn, soon to inherit Hudson's mantle as a leading scholar of international law at Harvard, and mentor to many of today's senior scholars in the field).

235. Hauser, supra note 200 , at 18. 
clearly unfavorable assessment written roughly a decade after the trial.

Perhaps this is New Deal justice--the overriding of precedent, the fight against the 'nine old men' who successfully stood out for precedent against administrative absolutism-transferred to the international scene, where no carefully administered law stood in its way. It is also New Deal jurisprudence without the tempering of justice with humanitarianism in which it usually prided
itself. 236

These criticisms highlight how the Nuremberg Charter might also be seen as a New Deal-style institution; an example of a Rooseveltian synthesis of the legalistic and moralistic idioms of American multilateralism. At first glance-and perhaps even at second-the Nuremberg trial hardly seems like an internationalization of the New Deal. Yet a fresh take on Nuremberg might portray the trial as a pragmatic administrative pastiche-an innovation in international organization as well as in international law.

The Nuremberg Charter, in particular, appeared to many contemporary commentators as a concrete realization of the hitherto unsupported, moralistic ideas of the post-World War I era, while also serving as an expression of the positivist strain of legalism from the earlier Hague era as well. Nuremberg was an attempt to express moralistic ideas in a legalistic manner, and in so doing, it teemed with internal contradictions. In true, pragmatic New Deal style, however, the trial also got the job done, while generating a minimal level of legitimacy denied to both the sterile Hague approach and the sentimental Pact of Paris approach. On a visit to Nuremberg to observe the trial, internationalist Senator Claude Pepper, Democrat of Florida, toasted Robert Jackson as "America's international district attorney." 237 Sending the defeated Nazis down the river was to be the international version of busting trusts and tackling American organized crime. 238

Signature snafus of the New Deal, such as ham-handed attempts to export domestic norms, personality clashes from unclear lines of authority, and haphazard, ideologically incoherent but ultimately pragmatic legal theories were abundantly present at the trial as well. Indeed, the colloquial term "snafu" was constantly on everyone's lips at Nuremberg. ${ }^{239}$ Major players designing, administering, and advising behind the scenes were prominent New DealersJackson himself, of course; the American judge, Francis Biddle; senior presidential aide and Roosevelt speechwriter, Judge Samuel Rosenman; and other, more peripheral advisors such as Harry Dexter White, Harry Hopkins, and Supreme Court Justice Felix Frankfurter. In addition, many of the second-tier participants designing and implementing the trial had served as aides and assistants to New Deal bureaucrats. Examples included assistant prosecutor Telford Taylor; designer of the original "conspiracy" structure, Murray Bernays;

236. AlfRed Vagts, Defense and Diplomacy: The SOldier and the Conduct of FOREIGN RELATIONS 327 (1956).

237. TAYLOR, supra note 7, at 216 (quoting Senator Claude Pepper).

238. Id.

239. Simon Diary, supra note 34 (entry for Nov. 12, 1945) (“As usual it's snafu."). 
former general solicitor of the Southern Railway, Sidney B. Alderman; Columbia law professor Herbert Weschler; Adrian S. Fisher, a Harvard law graduate who had clerked for Justices Frankfurter and Brandeis; and James H. Rowe, former confidential assistant to FDR and another Harvard law graduate who, like Judge Biddle, had clerked for Justice Oliver Wendell Holmes. ${ }^{240}$

While the jurisprudence underlying Nuremberg's Charter was an unstable amalgam of natural law, common law, and traditional positivist reasoning, the Tribunal's main contribution to postwar multilateralism was arguably through its quasi-administrative, fact-finding role - another cherished objective of New Deal-style institutions. It told the truth about the Nazis, even if it fell short of serving as "the greatest history seminar ever held in the history of the world." 241

$$
\begin{gathered}
\text { X. } \\
\text { NUREMBERG AS A HUMAN RIGHTS INSTITUTION: “I AM A HUMAN BEING, AND I } \\
\text { BELIEVE THAT NOTHING THAT IS HUMAN IS ALIEN TO ME" } 242
\end{gathered}
$$

In his memoir of the Nazi concentration camps, If This Is a Man, Italian chemist Primo Levi recounted how he sought to escape the grueling outdoor labor brigade that was slowly killing him in the winter of 1943-44. A low-level position had opened up in one of the chemical laboratories that supported the forced-labor factory system at Auschwitz. Having earned a doctorate in chemistry from the University of Turin only two years before, Levi desperately hoped to secure one of these coveted laboratory jobs, guaranteeing indoor work and exemption from monthly selections for the gas chambers.

In a famously vivid scene, the young Italian-Jewish partisan was interviewed by the director of the chemical department, a German "Doktor Ingenieur" named Pannwitz. In his filthy inmate uniform, Levi stood awkwardly in Pannwitz's shining office, fixating on the German's manicured hands and feeling "that I would leave a dirty stain whatever I touched."243 After a few moments, the seated scientist stopped writing and raised his eyes to look at Levi.

It was a gaze which Levi would remember all his life, the author later explained, "[b]ecause that look was not one between two men; and if I had known how completely to explain the nature of that look, which came as if across the glass window of an aquarium between two beings who live in different worlds, I would also have explained the essence of the great insanity of

240. On the junior New Dealers at Nuremberg, see TAYLOR, supra note 7, at 119, 127, 143.

241. IAN Buruma, THE Wages OF GUILT: MEMORIES OF WAR IN GermanY AND JAPAN 144-45 (1994) (quoting Nuremberg assistant prosecutor Robert M. Kempner).

242. Publius Terentius, Rome, c159 B.C. This was a favorite saying of Tokyo War Crimes Trial Assistant Prosecutor Kurt Steiner. Dr. Steiner was an interview subject for this study and a mentor of the author.

243. PRIMO Levi, IF THIS IS A MAN AND The TRUCE 111 (Stuart Woolf trans., Penguin Books 1979) (1947) (originally published as Se questo è un uomo). The Truce, which was an account of Levi's eventful homeward journey from Poland, was originally published in 1963 as La tregua; today, the two short memoirs are often published together. 
the third Germany [Third Reich]."244

Human rights expert Michael Ignatieff has written brilliantly of this scene: "Here was a scientist [Pannwitz], trained in the traditions of European rational inquiry, turning a meeting between two human beings into an encounter between different species."245 Ignatieff continues: "Progress may be a contested concept, but we make progress to the degree that we act upon the moral intuition that Dr. Pannwitz was wrong: our species is one, and each of the individuals who compose it is entitled to equal moral consideration."246

Nuremberg embodied the first institutionalized, multilateral attempt to use the ideals of the rule of law to give voice to this moral intuition. It was the flagship event of what Ignatieff calls "'the juridical revolution' in human rights since 1945."247 While the bare language of the Nuremberg Charter was not phrased using modern human rights terminology, the trial's context of genocide and atrocity transformed how the proceedings came to be understood over time. The focus thus far has been on how contemporary planners saw the trial and how commentators received their efforts in the short term. However, an important paradox of Nuremberg as a human rights institution is the gap between what the architects of Nuremberg thought they were doing, and how the perceived human rights lessons of the trial have changed over time. While a full review of changing interpretations of Nuremberg in the postwar era is beyond the scope of this article, some human rights-related implications of this paradox are touched on below.

Law professor Martha Minow describes as "devastating" the yawning gap "between the capacity of the trial form with its rule of law and the nature of mass atrocities."248 The existence of such a gap may go a long way toward explaining the paradox of the Nuremberg legacy. One of the main reasons that the trial is often overlooked as a fountainhead of human rights culture is the strange divergence between what the Nuremberg Charter purported to be about-primarily, the outlawry of aggressive war-and what the trial is in fact remembered for today-namely, the landmark delineation of crimes against humanity in a context of holocaust and genocide. To say, as historian William Bosch did as late as 1970, that "[t]he Tribunal's most significant legal innovation was its legal definition of aggression as the "supreme crime," now reads as a singularly off-key interpretation of what was actually going on

244. Id. at 111-12.

245. Michael IgnatiefF, Human Rights as Politics and Idolatry 3 (Amy Gutmann ed., 2001) (delivered as the Tanner lectures on Human Values at Princeton University, 2000).

246. Id. at 3-4. Such arguments about innate human dignity were the polar opposite of the cultural and scientific orientation of the Third Reich. See generally, for example, the accounts of Nazi philosophy in ROBERT JAY LIFTON, THE NAZI DOCTORS: MEDICAL KILLING AND THE PSYCHOLOGY OF GENOCIDE (1986); JAMES M. GLASS, LIFE UNWORTHY OF LIFE (1997). Ignatieff).

247. Amy Gutmann, Introduction, to IGNATIEFF, supra note 245 , at vii (quoting Michael

248. MARTHA MINOW, BETWEEN VENGEANCE AND FORGIVENESS: FACING HiSTORY AFTER GENOCIDE AND MASS VIOLENCE 47 (1998). 
beneath the trial's rhetorical surface. ${ }^{249}$

Recent commentators are sometimes surprised that the word "genocide" does not appear in the Nuremberg Charter, although the term does appear in some of the supporting court papers, including the Indictment-the first use of that term in an international legal instrument. 250 As with the 1941 Atlantic Charter (a document which does not use the phrase "human rights"), the Nuremberg Charter was instrumental in crystallizing a pre-existing concept in a new way, for which a modern vocabulary rapidly developed.

An advisor to the American prosecution staff, the Polish-Jewish refugee and Yale international legal scholar Raphael Lemkin, had coined the term "genocide" in the course of his wartime research, writing, and advocacy on behalf of victims of the Third Reich. 251 Lemkin's formulation first appeared in his massive 1944 volume, Axis Rule in Occupied Europe, published by the Carnegie Endowment for International Peace. Lemkin defined genocide as:

[an intentionally] coordinated plan of different actions aiming at the destruction of essential foundations of the life of national groups, with the aim of annihilating the groups themselves. The objectives of such a plan would be disintegration of the political and social institutions, of culture, language, national feelings, religion, and the economic existence, of national groups, and the destruction of the personal security, liberty, health, dignity, and even the lives of the individuals belonging to such groups .... [T] he actions involved are directed against individuals, not in their individual capacity, but as members of the national group. ${ }^{252}$

The New York Times Book Review featured a full page on Lemkin's dense and technical tract on the cover of its January 21, 1945 issue. ${ }^{253}$ "For out of its dry legalism," wrote reviewer Otto Tolischus, "there emerge the contours of the monster that now bestrides the earth." 254 Lemkin commented in a draft of his next book, begun in 1944 but never published, that acceptance and use of a new term can only happen "if, and so far as, it meets popular needs and tastes.",255

Part of the impetus for developing this new vocabulary was the experience

249. See BosCH, supra note 191 , at 14 .

250. "[The defendants] conducted deliberate and systematic genocide, viz., the extermination of racial and national groups, against the civilian populations of certain occupied territories in order to destroy particular races and classes of people and national, racial, or religious groups, particularly Jews, Poles, and Gypsies and others." Indictment, in 1 IMT NUREMBERG, supra note 2, at 43-44.

251. See Taylor's account of preparing the Indictment, where he notes that over the objections of a member of the British prosecution team, "we used the word 'genocide,' newly coined by Raphael Lemkin." TAYLOR, supra note 7, at 103.

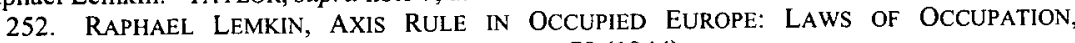
ANALYSIS OF GOVERNMENT, PROPOSALS FOR REDRESS 79 (1944).

253. Otto D. Tolischus, Twentieth-Century Moloch: The Nazi-Inspired Totalitarian State, Devourer of Progress-and of Itself, N.Y. TIMES BOOK REV., Jan. 21, 1945, at 1.

254. Id.; see also Waldemar Kaempffert, Genocide is the New Name for the Crime Fastened on the Nazi Leaders, N.Y. TIMES, Oct. 20, 1946, at EI3.

255. Samantha POWER, "A Problem From Hell": America and the AGE of Genocide 44 (2002) (quoting Raphael Lemkin, History of Genocide, reel 3, 1:7, Lemkin Papers). See id., at 29-78 for Power's excellent account of Lemkin's influence. 
of actually litigating the trial itself, exposing flotillas of articulate young attorneys to the numbing details of vast numbers of atrocities. The evidence underlying the charge of crimes against humanity at Nuremberg was simultaneously vivid to the point of luridness and so unimaginable that, ordinarily, the mind must draw a veil over their particulars. Such a psychologically self-protective response was not always possible for the prosecution staff at Nuremberg, as well as for those members in charge of prisoners, documents, and exhibits. The French doctor in charge of the trial exhibits relating to atrocities fingered a set of decorative objects made out of flayed, tattooed human skin-exhibits which have since become iconic symbols of Nazism - and observed ruminatively to Rebecca West:

These people where I live send me in my breakfast tray strewn with pansies, beautiful pansies. I have never seen more beautiful pansies, arranged with exquisite taste. I have to remind myself that they belong to the same race that supplied me with my exhibits, the same race that tortured me month after month, year after year, at Mauthausen. 256

It was this deep substratum of horror, as much as the superficial atmospherics of legal improvisation, administrative chaos, and ersatz "colonialism" that underpinned the eccentric atmosphere at Nuremberg, remarked upon by so many commentators. Even at a remove of three generations, it induces a kind of mental short-circuit to ingest even the smallest quantities of this kind of evidence. ${ }^{257}$ In a 1946 letter to Karl Jaspers, Hannah Arendt wrote that the Nazi crimes exposed the limits of law, for no punishment could ever be sufficient. ${ }^{258}$ As the historian Lawrence Langer has recently written, "the logic of law will never make sense of the illogic of extermination." 259

Yet this substratum of horror itself became an engine of cultural transformation, reshaping how the trial's legal ideas were understood. British barrister and human rights advocate Geoffrey Robertson vividly elaborates how "the spontaneous drama of the [Nuremberg] courtroom provided the defining moment of de-Nazification on the afternoon when the prosecutor showed newsreels of Auschwitz and Belsen and the defendants, spotlit for security in the dock, averted their eyes."260 While the charges of wáging aggressive war were

256. WEST, supra note 22 , at 21 .

257. See Naomi Mor, Holocaust Messages from the Past, 12 CONTEMP. FAM. THERAPY 371 (1990). This exposure took a psychological toll on the Nuremberg staff, arguably contributing to the bizarre suicide in the exact manner of Goering of prison psychiatrist Douglas Kelley.

258. Arendt speculated that this is why the Nazis in the dock seemed so smug. Letter from Hannah Arendt to Karl Jaspers (Aug. 17, 1946), in HANNAH ARENDT-KARL JASPERS CORRESPONDENCE, 1926-1969, at 54 (Lotte Kohler \& Hans Saner eds., Robert Kimber \& Rita Kimber trans., 1992).

259. LaWrence L. Langer, Admitting the Holocaust 171 (1995). Consider, for example, this summary of the aftermath of the sporadic British bombing of the factories and railroad yards around Auschwitz in September of 1944: camp inmates wounded by the bombardment "were given first-class medical treatment and even received flowers and chocolate from the SS. Then, with consistent incongruity, the Nazis exterminated the recovered inmates." CONOT, supra note 11, at 9.

260. Geoffrey Robertson, CRIMES Against Humanity: THE StrugGle For Global 
arguably the focus of the Nuremberg Charter on paper, in practice it was the evidence regarding crimes against humanity that soon became what political theorist Judith Shklar termed "the moral center of the case."261

XI.

“[I]T WAS OBVIOUS THAT THE TRIBUNAL MUST SIT TO DISPROVE JOB'S LAMENT THAT THE HOUSES OF THE WICKED ARE SAFE FROM FEAR.",262

Human rights legacies of Nuremberg that were immediately apparent included legitimating the idea of individual responsibility for crimes against international law; offering a jurisprudential underpinning for political or philosophical assertions of the dignity of the individual, irrespective of local, domestic laws; and providing an example of the importance of documenting and narrating the specifics of atrocities to create a detailed and enduring record. Even the trial's least successful legacy, its attempt to consolidate the status of aggression as an international crime, shaped the direction of human rightsrelated legal ideas, away from policing the political context of armed conflict, and more towards the protection of civilians.

Another important facet of the trial's rule of law legacy was procedural, exemplified by the opportunity for those facing criminal charges to be heard individually, to defend their actions, and to be confronted with the specific evidence against them. Robertson argues that, "the most astonishing feature of Nuremberg" was in fact the German defendants' own evolving perception of this procedural fairness; the gradual process through which "the adversary dynamics of the Anglo-American trial sucked in the defendants, who played an earnest and polite, [and] at times desperate, part in making it work."263

Robertson explains the link between human rights ideas regarding individual dignity and Nuremberg's development of the pre-existing, although somewhat inchoate, idea of crimes against humanity:

[Nazi atrocities] were crimes that the world could not suffer to take place anywhere, at any time, because they shamed everyone. They were not, for that crucial reason, crimes against Germans [;] . . they were crimes against humanity, because the very fact that a fellow human could conceive and commit them diminishes every member of the human race. ${ }^{264}$

He argues that Nuremberg earned its status as a human rights landmark "for this precedent alone." 265

\footnotetext{
JUSTICE 215 (1999).

261. JUDITH N. SHKLAR, LEGALISM 170 (1964).

262. WEST, supra note 22 , at 50.

263. ROBERTSON, supra note 260 , at 216 (noting that, "[the defendants'] leader, Goering, had initially advised them to confine their evidence to three words: 'Lick my arse'-the defiant catchcry of one of Goethe's warrior heroes"); see also Benjamin B. Ferencz, Nurnberg Trial Procedures and the Rights of the Accused, 39 J. CRIM. LAW \& CRIMINOLOGY 144, 146-50 (194849).

264. ROBERTSON, supra note 260 , at 220

265. Id.
} 
Ideas about individual dignity also had a collective element, elaborating this sharper sense of the shared qualities of all humanity. Author and columnist for the liberal daily PM, Max Lerner, saw Nuremberg as a kind of public ritual, where the international community could attempt, through "an immense and revolutionary effort to give utterance to a collective human conscience, to bring into being a collective standard by which gross violations of that conscience can be punished." 266 Lerner continued:

[S]ome may gibe that I am speaking of a 'human conscience' and a 'moral sense' that are vague and formless, things on which no body of law can be built. I submit that they are the only things that a body of law ever rests on. The surest basis of a future world society lies in the sense of our common plight. When a Negro is lynched, all of us are strung upon that rope. When the Jews were burned in the Nazi furnaces, all of us were burned. ${ }^{267}$

Law professor Thomas Franck explains succinctly how the Nuremberg ideas served to reconfigure the individual's relationship to his or her own national law:

The international war crimes trials which followed the demise of Hitler's Evil Empire gave powerful impetus to the notion that there is a global system-based duty to disobey positive law when it serves demonic ends. This episode briefly succeeded in focusing attention on an international rule system which is the repository of inalienable rights, rights that may even have the capacity to invalidate the duty to obey national laws. 268

The Nuremberg judges themselves explained that "the very essence of the Charter is that individuals have international duties which transcend the national obligations of obedience imposed by the individual state."269 This idea of the supra-national quality of certain rights was incorporated into the constitution of the Federal Republic of Germany; under Article 25, general rules of international law took precedence over German federal law, while Article 26 decreed it unconstitutional to prepare for acts of aggression. ${ }^{270}$ These human rights legacies "sit at the foundation of the rule of law," as they reinforce norms that constrain governments against arbitrary conduct, a notion that Minow terms "fundamental fairness."271

The idea of an individual owing obedience to laws based on what this study has termed general "Martens clause" standards-laws that may or may not be codified, are constantly changing, and that stand in for ideas of "civilization" with alarming racialized antecedents-troubles many commentators.

266. MaX LeRner, ACtions and Passions: NOtes on the Multiple ReVolutions of OUR TIMES 263 (1948)

267. Id.

268. Thomas Franck, The POWER of Legitimacy Among Nations 12 (1990).

269. I IMT NUREMBERG, supra note 2, at 223.

270. See the description of constitutional provisions in WHITNEY R. HARRIS, TYRANNY ON TRIAL, 568 (rev. ed. 1999) (1954). On codification of the so-called Nuremberg Principles at the United Nations level, see U.N. GAOR, 5th Sess., Supp. No. 12, U.N. Doc. A/1316 (1950), reprinted in Report of the International Law Commission Covering Its Second Session, June 5-July 29, 1950, 44 AM. J. INT'L L. Sup. 105, 125-34 (1950).

271. MiNow, supra note 248 , at 29. 
Philosopher Peter Haas notes:

One area of human endeavor that claims to stand above individual choices and institutional vagaries is the law.... But what about a law that transcends individual political structures? Can an 'international law' be jnvoked that might pass judgment on national legal systems that have run amok?

Haas is doubtful: "Like individual state laws ... [i]nternational law no more than any other law can transcend its origins." ${ }^{273}$ He continues:

The assumption behind the [Nuremberg] trials was apparently that 'international law' could somehow establish a reference point that would provide the fulcrum needed to prevent similar events. It is also probably true that the trials were motivated at least in part by an attempt ex post facto on the part of the Allies to distance themselves, after years of silence and inaction, from the deeds of the Nazis. ${ }^{274}$

This search for such a "fulcrum" remains the central problem of modern human rights theory. Philosopher Michael Perry has recently argued that ideas about human rights based on theories of innate human dignity must ultimately be based on religious cosmologies. ${ }^{275}$ Other scholars, such as the Kantians Alan Gewirth and Christine Korsgaard and the legal theorists Ronald Dworkin and Eric Blumeson, have developed ideas about human dignity based on secular arguments about the human capacities for reason, suffering, or empathy. ${ }^{276}$ Several of these theorists have argued that another such secular base for the unique sanctity of the human might indeed be simple intuition. 277

Whatever the competing merits of these arguments, at some point our philosophical spade is turned, and always before striking the satisfying bedrock

272. Peter J. HaAs, Morality after Auschwitz: The Radical Challenge of the NAZI ETHIC 203 (1988). Haas' question implicates a fascinating postwar debate in American jurisprudence, between the positivist H.L.A. Hart and the natural law theorist Lon Fuller. Questions at the secondary Nuremberg trials about the validity of defenses resting on prior Nazi laws sparked the Hart-Fuller debate about the nature of law itself. Hart argued that antecedent laws must be construed as valid until replaced, while Fuller argued that the rule of law meant that Germany had to restore "both respect for law and respect for justice" even though "painful antinomies were encountered in attempting to restore both at once." See Lon L. Fuller, Positivism and Fidelity to Law-A Reply to Professor Hart, 71 HARV. L. REV. 630, 657 (1958); see also H.L.A. HART, Positivism and the Separation of Law and Morals, 71 HARV. L. REV. 593 (1957).

273. HAAS, supra note 272, at 203.

274. Id.

275. MiCHAEL J. PERRY, THE IDEA OF HUMAN RIGHTS: FOUR INQUIRIES 16 (1998).

276. See Eric Blumenson, Who Counts Morally? 14 J.L. \& RELIGION 1-40 (1999-2000); ALAN GEWIRTH, THE COMMUNITY OF RIGHTS 19 (1996); Christine Korsgaard, Two Distinctions in Goodness, 92 PHIL. REV. 169 (1983); RONALD DWORKIN, LIFE's DOMINION: AN ARGUMENT ABOUT ABORTION, EUTHANASIA, AND INDIVIDUAL FREEDOM (1994).

277. On the role of intuition, Blumenson cites Thomas Nagel, Pierre Schlag, and, of course, Ludwig Wittgenstein for the proposition that:

the human rights idea might be fully legitimate without any intellectually articulable foundation at all ... . Clearly this is true of some other kinds of knowledge-the kind of intuitive knowledge we draw on when we recognize a family resemblance, anticipate a musical progression, or speak grammatically without knowing the rules.

Blumenson, supra note 276, at n.6. Recent anthropological evidence also points to certain kinds of universal human reactions that may have moral overtones, such as expressions indicating disgust. See Malcolm Gladwell, Annals of Psychology: The Naked Face, NEW YORKER, Aug. 5, 2002, at 38. 
of what Richard Primus skeptically calls "the true grounds underlying a claim of rights." 278 Recent work in the new field of "transitional justice" also suggests that it may be fine simply to stop digging. As Judith Shklar observed, "[i]n fact, although it is philosophically deeply annoying, human institutions survive because most of us can live comfortably with wholly contradictory beliefs.",279 Scholars arguing for transitional justice approaches use ideas about value pluralism to do an end-run around static foundationalist debates about rights. Instead they emphasize the importance of history; specifically, the context of fluid political moments that highlight how "the social understanding behind a new regime committed to the rule of law" can be created. In the case of Nuremberg, part of the political context was the inevitable chaos involved in the transition from war to peace.

The emerging transitional justice paradigm posits an alternative way of thinking about the relation of law to political transformation. This school of thought asserts that justice is distinctive in times of transition-partial, contingent, and shaped by social understandings of prior injustice rather than by abstract, idealized conceptions of the rule of law. An approach emphasizing the transitional nature of the Nuremberg approach would suggest re-situating the trial in a political and cultural context of broader denazification programs, and not just as an isolated event in the world of legal ideas. ${ }^{280}$

The Nuremberg criminal trial might best be understood as an alternative to competing schemes such as the Morgenthau Plan, which emphasized the reparatory justice approach of disassembling industrial plants and the exporting of German labor to rebuild war-torn Allied countries. The transitional justice perspective sees international legal institutions as mediating "between facts and norms," that is, between the horrifyingly concrete realities of wartime events and aspirational abstractions such as "justice" and "security."281 Legal scholar Ruti Teitel sees international law itself as a "bridge" in transitional situations, "[g]rounded in positive law, but incorporating values of justice associated with natural law." 282

Nuremberg as a human rights institution is one example of this value pluralism. Along with the internally contradictory beliefs that Shklar found so annoying is the irritating fact that one of the more compelling sources of legitimacy for Nuremberg has always been the unappealing nature of the alternatives. While some commentators, such as Robertson, saw vindictiveness or hypocrisy in the use of the death penalty, this outcome was surely less vindictive than the alternatives of drumhead court martials or summary executions. Such an argument freely concedes the flaws embedded in the

278. Richard A. Primus, The American Language of Rights 8 (1999).

279. SHKLAR, supra note 261 , at $\mathbf{x}$.

280. Ruti G. TEITEl, TRANSITIONAL JUSTICE 13-15 (2000).

281. See William E. Forbath, Habermas's Constitution: A History, Guide, and Critique, 23 LAW \& SOC. INQUIRY 969 (1998).

282. TEITEL, supra note 280 , at $20-21$. 
controversial issues such as the victors' justice and tu quoque arguments. A contemporary editorial in the Christian Century explained:

The court was itself a guilty court and the prosecution was a guilty prosecution.

This terrible fact has to be admitted. The trial at Nuremberg was like an angel born in a brothel .... [T] he plain truth is that if justice of any kind is to be done anywhere in the world of today it will have to be done by the guilty. ${ }^{283}$

In his opening statement, Sir Hartley Shawcross, British chief prosecutor at Nuremberg, confidently expressed a widely-held aspiration for what Nuremberg would come to stand for: "[T]his Tribunal", he asserted, "will provide a contemporary touchstone and an authoritative and impartial record to which future historians may turn for truth, and future politicians for warning." 284 While this "impartiality" was certainly contested, Rebecca West noted with uncharacteristic plainness that, "[w]e had learned what they did, beyond all doubt, and that is the great achievement of the Nuremberg trial." 285

Goering himself acknowledged the importance of the seemingly modest objective of getting the facts out, as psychologist Gilbert recounted. "Brooding in his cell, Goering admitted that his attempt to build a heroic legend had been a failure. 'You don't have to worry about the Hitler legend any more,' he told me. 'When the German people learn what has been revealed at this trial, it won't be necessary to condemn him. He has condemned himself.,",286

Yet Nuremberg was more than a catalogue of facts. It was an attempt, however flawed, to approach William Butler Yeats's ideal of holding "reality and justice in a single vision." 287 A trial itself is a kind of dialogue, and essayist Elie Wiesel has argued that this act of dialogue has intrinsic value. "What emerges for Wiesel," writes Haas, "is the recognition that true comfort and reconciliation come only when the victim is able to share the pain with others

.... [Only in] dialogue with fellow human beings is there any foundation for hope and reconstruction." 288 For Wiesel, "acquiescence ... is the greatest danger, the silent onlooker the most troubling character."289

The alternative of amnesty-"silence," as Minow terms it-would have been similarly unconscionable, itself "an unacceptable offense, a shocking implication that the perpetrators in fact succeeded, a stunning indictment that the present audience is simply the current incarnation of the silent bystanders" who

283. Editorial, Majestic Justice, 63 CHRISTIAN CENTURY 1239-40 (1946)

284. 3 IMT NUREMBERG, supra note 2, at 92.

285. WEST, supra note 22 , at 60.

286. Gilbert, supra note 17 , at 228.

287. James Ryerson, The Quest for Uncertainty: Richard Rorty's Pragmantic Pilgrimage, LINGUA FRANCA 48 (2000-01) (quoting William Butler Yeats) (internal quotation omitted).

288. HAAS, supra note 272 , at 226.

289. Id. at 227. Haas argues further that one of the intellectual underpinnings of this discursive approach is a specifically theological strand of human rights philosophy, which he traces to Jewish traditions of enlightenment through dialogue. "Jewish thinking has always dealt with these tensions through the midrashic method, that is, by creating stories and myths that allow the individual to find meaning within the tensions." $I d$. at 223 . Such an approach arguably adds a new layer of irony to Hitler's famously contemptuous reference to "[c]onscience, this Jewish invention." HERMANN Glaser, The CultUral RoOts of National SOCIALISM 221 (1978) (quoting Hitler). 
had been complicit in the Nazi regime. ${ }^{290}$ President Truman overstated the case in 1946 when he indicated that the trial had realized his "high hope that this public portrayal of the guilt of these evildoers will bring wholesale and permanent revulsion on the part of the masses of our former enemies against war, militarism, aggression, and notions of race superiority."291 But the essence of the human rights point about Nuremberg was that through measured judicial retribution-not silent amnesty or indiscriminate vengeance--"the community correct[ed] the wrongdoer's false message that the victim was less worthy or valuable than the wrongdoer.",292

290. MNOW, supra note 248 , at 5.

291. Harry S. Truman, Message to the Congress on the State of the Union and on the Budget for 1947 (Jan. 21, 1946), in PUBLIC PAPERS, JANUARY 1 TO DECEMBER 31, 1946, at 46.

292. MINOW, supra note 248 , at 12. 